Review

\title{
Colorectal cancer defeating? Challenge accepted!
}

\author{
S. Di Franco a ${ }^{\text {, M. Todaro }}{ }^{\text {a }}$ F. Dieli ${ }^{\text {b }}$, G. Stassi ${ }^{\text {a,* }}$ \\ ${ }^{a}$ Department of Surgical and Oncological Sciences, University of Palermo, Via Liborio Giuffre' 5, 90127 Palermo, Italy \\ ${ }^{\mathrm{b}}$ Division of Immunology and Immunogenetics, Department of Biotechnology and Medical and Forensic Biopathological (DIBIMEF), Palermo, Italy
}

\section{A R T I C L E I N F O}

\section{Article history:}

Available online 5 August 2013

\section{Keywords:}

Colorectal cancer

Cancer stem cell

Tumour microenvironment

Immune system

Targeting

Individualized therapy

\begin{abstract}
A B S T R A C T
Colorectal tumours are actually considered as aberrant organs, within it is possible to notice a different stage of cell growth and differentiation. Their origin is reported to arise from a subpopulation of tumour cells endowed with, just like the healthy stem cells, selfrenewal and aberrant multi-lineage differentiation capacity likely to be called colorectal cancer stem cells (CCSCs). Cancer stem cells (CSCs) fate, since their origin, reflects the influences from their microenvironment (or niche) both in the maintenance of stemness, in promoting their differentiation, and in inducing epithelial-mesenchymal transition, responsible of CSCs dissemination and subsequent formation of metastatic lesions. The tumour cells heterogeneity and their immuno-response resistance nowadays probably responsible of the failure of the conventional therapies, make this research field an open issue. Even more importantly, our increasing understanding of the cellular and molecular mechanisms that regulate CSC quiescence and cell cycle regulation, self-renewal, chemotaxis and resistance to cytotoxic agents, is expected to eventually result in tailor-made therapies with a significant impact on the morbidity and overall survival of colorectal cancer patients.
\end{abstract}

(c) 2013 Elsevier Ltd. All rights reserved.

\section{Contents}

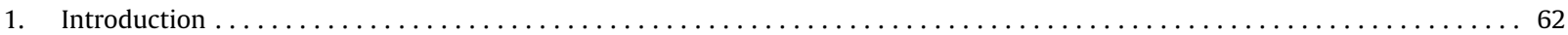

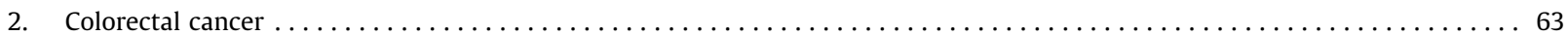

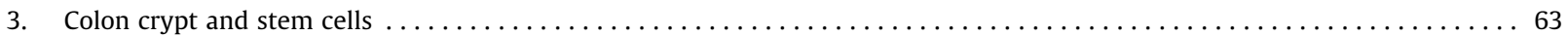

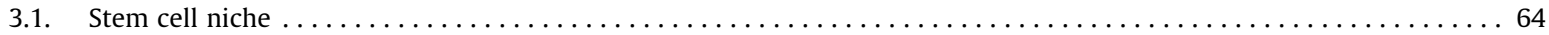

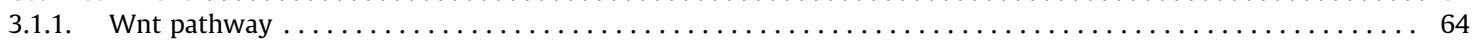

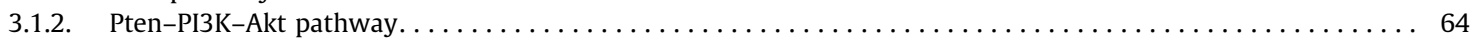

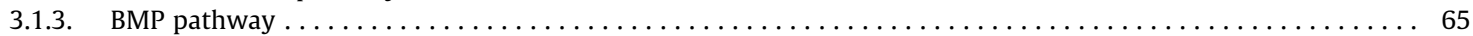

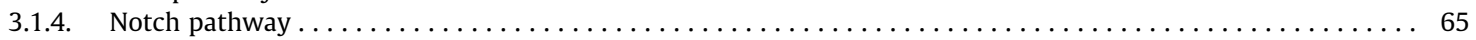

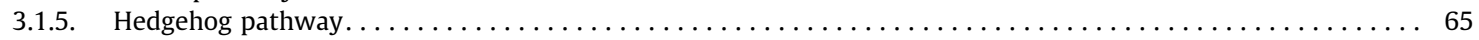

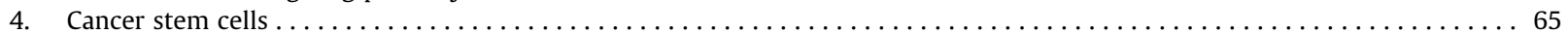

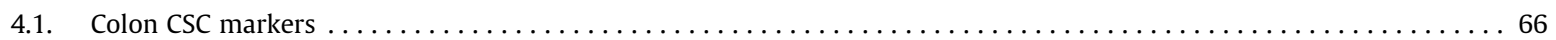

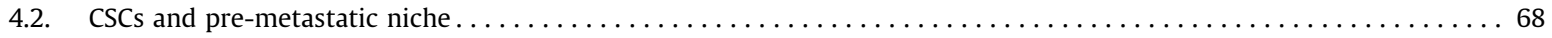

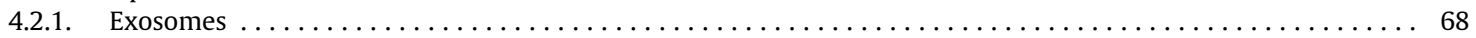

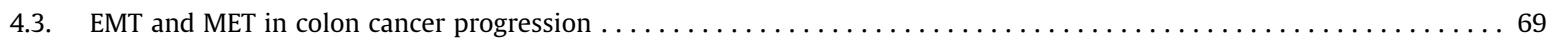

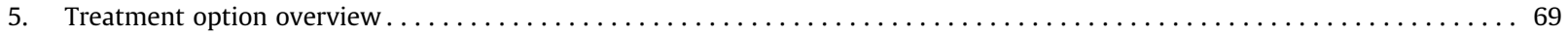

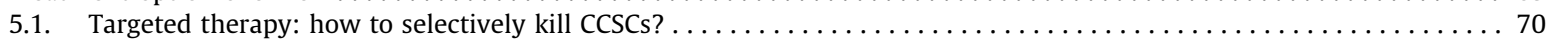

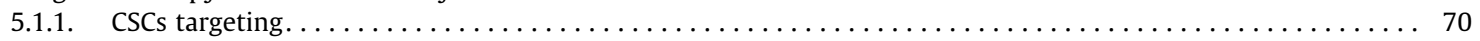

\footnotetext{
* Corresponding author. Address: Policlinico Paolo Giaccone, Via Liborio Giuffre’ 5, 90127 Palermo, Italy. Tel.: +39 0916552676 ; fax: +39 0916553238. E-mail address: giorgio.stassi@unipa.it (G. Stassi).
} 


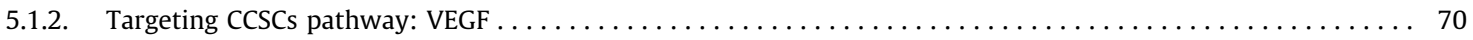

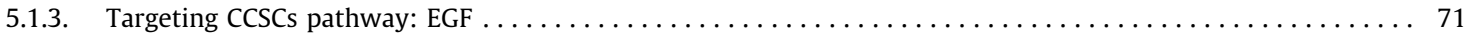

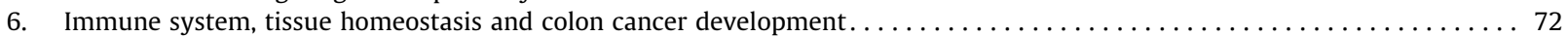

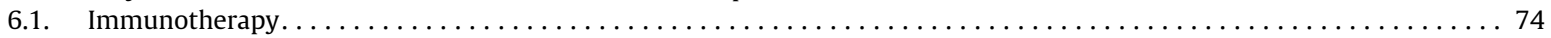

7. Individualized therapies. . . . . . . . . .

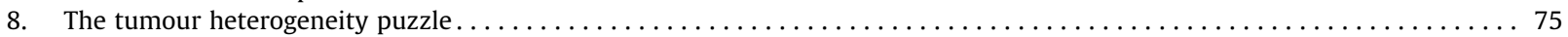

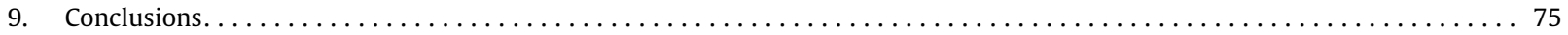

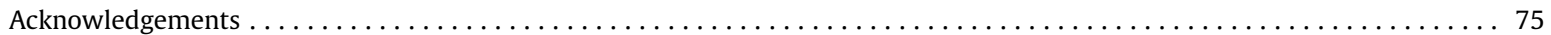

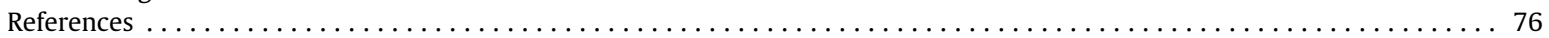

\section{Introduction}

Colorectal cancer (CRC) is one of the major causes of death worldwide (Jemal et al., 2011). Despite the prompt surgical removal followed by adjuvant therapy, often suitable in the early stages of the disease, the majority of patients undergo to recurrences and metastases. This phenomenon frequently correlates with an acquired resistance to conventional therapies such as chemo- and radio-therapy (Jänne and Mayer, 2000).

Increasing evidences recently claimed that tumours are structured by heterogeneous populations of cells hierarchically organized, with CSCs at the top of this pyramid model. The concept that this subset of cells may arise from normal stem cells (or progenitor cells), as a result of genetic and/or epigenetic mutations (Barker et al., 2009) is appealing for several reasons. Healthy stem cells and CSCs share many properties, including the self-renewal and aberrant multi-lineage differentiation capacity, altered DNA repair machinery, high expression levels of anti-apoptotic genes and ATP-binding cassette (ABC) transporters, which could explain the failure of current anti-cancer treatments (Todaro et al., 2007). Moreover, the CSCs are highly clonogenic and can generate a serially transplantable phenocopy of the primary malignancy in immuno-compromised mice (Clarke et al., 2006), highlighting their tumourigenic capacity.

The amazing cellular turnover of the colon epithelium makes this tissue the ideal subject for the study on the healthy stem cells biology, and then on cancer stems cells during tumour progression. Under physiological conditions, colon homeostasis is highly regulated, and it is the result of a perfect balance between stem cells, differentiated cells and the microenvironment. Sometimes, however, this balance is missing, so throwing the foundations for the emergence and progression of the tumour.

It has been noticed that the colon stem cells (SCs) reside at the base of the intestinal crypts, where the microenvironment seems to orchestrate the stemness status, the proliferation and the resistance to apoptosis of stem cells, regulating different signaling pathways. This network of signals link up different stromal cells, such as mesenchymal cells with immune cells, blood vessels, soluble factors and extracellular matrix components (Kosinski et al., 2007) building the complex tumour architecture. Likewise the CSCs are strictly dependent from their residing environment, the tumour niche, which not only play a role in determining the cell type, but also provides protection by sheltering CSCs from diverse genotoxic insults, contributing to their enhanced therapy resistance (Sun and Nelson, 2012).

Most conventional therapies affect differentiated cells, which constitute the bulk of tumour mass, thus saving CSCs. This phenomenon seems to be the cause of the initial tumour shrinkage followed by relapses, often more aggressive of the primary tumour of origin (Al-Hajj et al., 2004).

Nowadays, thanks to new quick and low-cost technologies, it is possible to achieve genomic and proteomic analysis to better characterize the tumour patient "phenotype" considering that the "one-size-fits-all" approach for cancer treatment is not longer sufficient. These "omics" analyses have pushed a new personalized approach in the cancer field, trying to optimize the treatment options, to avoid the resistance phenomena, bypassing unnecessary side effects (Chang et al., 2009; Wilson et al., 2007).

The origin and tumour progression are tightly regulated by aberrant oncogenic pathways activation, in concert with an inactivation of tumour suppressor signals. This phenomenon, however, seems to follow a branched trend, rather than linear, thus generating a large clonal diversity, and contributing to the intra-tumoral genetic heterogeneity (Marusyk et al., 2012). The huge inter-tumour variability depends from several aspects, first of all the variables related to the host (age, hormonal status), while the intra-tumour cellular organization is differentially influenced by several stimuli coming from the contiguous microenvironment (differences in vascularity, infiltration degree, connective tissue components). Last but not least it is also important to consider the cellular state diversity, as the cell cycle, the exposure to antigens, and the membrane composition (Heppner, 1984).

This great heterogeneity poses a considerable number of questions on how to address the issue of tumour, both from the point of view of diagnosis and of the possible treatment suggested (Gerlinger et al., 2012), as we will discuss later in this review.

We recent demonstrated the role of different components of the immune system against the tumours (Tallerico et al., 2013; Todaro et al., 2009). Although there is strong evidence of how the cells of the immune system can limit tumour 
growth, other data indicated that prolonged and unresolved immune responses, such as chronic inflammation, can act promoting cancer growth and progression (Grivennikov et al., 2010; Shiao et al., 2011).

In spite of, it is evident that the tumour cells negatively regulate the immune system through the release of immunosuppressive factors (Sidler et al., 2011), and that the tumour infiltration by immune cells can be considered as a positive prognostic factor for the overall patient's survival (Pagès et al., 2010).

In light of the recent evidence, it will be interesting to deepening elucidate all the mechanisms regulating the immune surveillance within the tumour microenvironment to develop important new therapeutic strategies to be coupled to conventional therapies for better response to treatment.

\section{Colorectal cancer}

CRC progression is characterized by the progressive acquisition of at least 4-5 oncogenes mutations, or of tumour suppressor genes, determining a malignant tumour formation (Vogelstein et al., 1988), some of them occur often in the same genes and are commonly shared by most people affected by this malignancy, otherwise some mutations are acquired differently and they determine the final cancer phenotype (Fearon and Vogelstein, 1990).

Most of knowledge about colon cancer progression derived from the study of the its inherited form the familial adenomatous polyposis (FAP), an autosomal dominant CRC syndrome caused by the Adenomatous Polyposis Coli (APC) gene mutation which include about $10 \%$ of cases (Galiatsatos and Foulkes, 2006). The APC protein promotes the Wnt signaling pathway activation, and its main role is in modulating the cytoplasmic B-catenin levels, a protein that migrating to the nucleus can activate the transcription of several genes involved in cell proliferation, differentiation, migration and apoptosis (Fearnhead et al., 2001).

Tumour progression in these cases required also other related mutations such as KRAS, SMAD2/4, TP53 and deletion of chromosome 18q (Kinzler and Vogelstein, 1996).Recent mounting evidences suggest that cancer growth is fuelled by a cell subpopulation called cancer stem cells, not only important in establish the primary tumour but mostly in the metastatic processes and tumour recurrences (Croker and Allan, 2008; Li et al., 2007b).

Tumour metastasis formation is a complex process that involves a sequence of pathological events, starting with local invasion by tumour cells which must leave the primary tumour site, migrate through the blood and lymphoid vessels, to evade from the circulation and reach the distant tissue, in order to form a micrometastasis. A study on melanoma cells has shown that only $2 \%$ of these migrating tumour cells actually manage to form metastases to distant tissue (Luzzi et al., 1998). According to this hypothesis, this number actually reflects the amount of CSCs within the tumour population.

It was recently noticed that CSCs as the metastatic tumour cells, need to be closely in contact with a specific microenvironment to support their growth and to provide protection and contrary to differentiated tumour cells the CSCs are resistant to conventional therapies, (Lobo et al., 2007; Moitra et al., 2011), making them an ideal target to develop new therapy strategies.

\section{Colon crypt and stem cells}

Colon tissue is composed by the serosa, the muscolaris, the sub-mucosa and mucosa, as outer layer. It mainly consists of epithelial and goblet mucipare cells and it is surrounded by an absorptive and secretory epithelium, folded in a set of invaginations (about 14,000/square centimeter in the adult human colon), called crypts of Lieberkuhn.

Each crypt contains about 2000/3000 cells, belonging to different populations: the columnar cells, the muco-secreting goblet cells and a small fraction (about 1\%) of entero-endocrine cells (Booth and Potten, 2000; Brittan and Wright, 2002).

According to the "unitarian theory" all these cell types are generated by a colonic SC (4-6 SCs/crypt), located at the base of the crypt that, through an asymmetric division generate one stem cell (identical with self-renewal capacity) and one progenitor cell that can proliferate, differentiate and migrate to the top of the crypt (Cheng and Leblond, 1974; Kirkland, 1988; Paulus et al., 1992).

Several markers have been linked to the colon SCs, among these: Musashi-1 (Msi-1), B lymphoma Mo-MLV insertion region 1 homolog (Bmi1), Aldehyde Dehydrogenase 1 (ALDH1), EphrinB (EphB) receptors, and Leuchin-rich repeat-containing G protein-coupled receptor 5 (Lgr5).

Msi-1 is a RNA binding protein responsible for Drosophila melanogaster asymmetric division (Nakamura et al., 1994), it was the first molecule identified as a putative human colon SC marker. Its expression was reported in mouse small intestine and in human colon crypt SCs (Nishimura et al., 2003; Potten et al., 2003). Msi-1 appears also to regulate p21 and Notch-1 signaling, as demonstrated by its silencing that causes mitotic catastrophe and xenograft tumour growth arrest by Notch inhibition and p21 up-regulation (Sureban et al., 2008).

Another important putative marker for colon SC is Bmi-1 that has an crucial role in self-renewal of several tissues, as in hematopoietic system, breast and neural one, and it is predominantly expressed in the small intestine at the base of the crypts at the "+4" position, directly adjacent to the Paneth cells (Sangiorgi and Capecchi, 2008). Its expression marks the quiescent stem cells that proliferate in response to injury (Yan et al., 2012).

A more promising marker might be ALDH1, since its expression seems to correlate with the cells that exhibit stem cell properties: a small subset of colonic cells are $\mathrm{ALDH}^{+}$(less than $5 \%$ ), they localize at the bottom of normal colon crypts, 
and $\mathrm{ALDH} 1^{+}$sorted cells are able to generate a xenograft once engrafted in mice, contrary to the ALDH1 $1^{-}$population (Huang et al., 2009).

It was recently demonstrated that colon SCs are marked by high expression of EphB2 receptor, which is gradually silenced during cell differentiation (Merlos-Suárez et al., 2011). These important colon SC markers act regulating the migration and proliferation in colon epithelium, and their expression follows a gradient along the crypt, with the highest levels at bottom of the crypt, the so called "stem cell niche" (Holmberg et al., 2006).

In the same compartment at the base of crypt, some Lgr5 (Gpr49) positive cells were founded. Lgr5 is a trans-membrane protein coupled with G-protein. In murine system, it is expressed only in active cycling columnar cells that can differentiate into functional colonic epithelium lineages (Barker et al., 2007). Moreover it was recently demonstrated that a single Lgr5 ${ }^{+}$ cell is able to regenerate a complete crypt-like structure in vitro (Sato et al., 2009). Moreover Lgr5 is a target gene of the well defined Wnt signaling pathway and its expression identify mitotically active stem cells important in the homeostatic regeneration of the tissue (Yan et al., 2012).

\subsection{Stem cell niche}

The organization of the intestinal niche includes fibroblasts, endothelia and inflammatory cells, forming the appropriate environment that guarantees the pluripotency of SCs.

The intestinal sub-epithelial myofibroblasts (ISEMFs) are considered the most important players in the maintenance of the niche, which surround the colon SCs, at the base of the crypt, regulate organogenesis and tissue repair. Their growth is finely controlled by many factors that together with different cytokines maintain the fine balance between self-renewal and differentiation (Adegboyega et al., 2002; Powell et al., 1999).

We have recently demonstrated that the myofibroblasts and their secreted factors, as well as hepatocyte growth factor (HGF) have a key role in establishing the colon niche in colon crypts. We have shown that HGF can have an effect on differentiated cells restoring their stem cell phenotype (Vermeulen et al., 2010).

In addition, current data show that Wnt, Phosphoinositide 3-kinase (PI3K), Bone Morphogenetic Protein (BMP), Notch and Sonic Hedgehog (Shh) pathways are a prominent force controlling cell proliferation, differentiation and apoptosis along the crypt-villus axis, thus maintaining stem cell fate and niche homeostasis.

\subsubsection{Wnt pathway}

In the last 20 years much it was published about the role of Wnt induced-signal in the regulation of colon tissue development. The binding of Wnt ligands to their Frizzled receptors (Fz) prevents $\beta$-catenin degradation (by a complex containing APC and Axin1/2), thus permitting its translocation to the nucleus where it acts as a transcriptional factor, interacting to the TCF/LEF complex, and inducing several genes transcription involved in cell cycle regulation and proliferation (He et al., 1998). An aberrant activation of this pathway, due to mutation in APC or $\beta$-catenin genes is clearly linked to colon cancer development (Clevers, 2006).

The identification of all the $\beta$-catenin target genes has led to the awareness about the role of this pathway in the maintenance of stemness, even if recent studies suggest that different cell types respond differentially to Wnt signal, according to the cell localization along the crypt. In line with this model, it has also been demonstrated that there is a different expression of Wnt members along the crypt: mRNA for secreted Fz-related proteins were found at the base of the crypts where they act maintaining the cell stemness, otherwise their expression decrease toward the top of the crypt, where reside the differentiated cells, and where are also expressed Wnt inhibitors (Gregorieff et al., 2005).

Moreover, the best characterized stemness target gene of Wnt/ $\beta$-catenin pathway is Lgr5 (Barker et al., 2007), that such as c-myc and cyclin D1, is involved in cell proliferation of the transit-amplifying compartment (He et al., 1998; Shtutman et al., 1999; Tetsu and McCormick, 1999).

Furthermore the identification of EphB as a Wnt target has improved our knowledge about the role of Wnt in the intestinal morphogenesis regulation (Batlle et al., 2002), such as in the induction of epithelial differentiation and epithelialmesenchymal transition (regulating the expression of MMP7, laminin $\gamma 2$, Slug), important also for the tumour invasion (Brabletz et al., 1999; Crawford et al., 1999; Hlubek et al., 2001; van Es et al., 2005).

Of course the effect of Wnt pathway is the result of a combined effect with all other actors of the colon stem niche.

\subsubsection{Pten-PI3K-Akt pathway}

A second important pathway with a central role in stem niche regulation is the PTEN-PI3K-Akt pathway. PI3K is composed by the regulatory subunit p 85 that can bind the receptor tyrosin-kinase (RTK), thus activating the catalytic subunit p110, that can phosphorylate its substrates. This event leads to the phosphorylation of the Akt kinase (p-Akt) by PDK1. PI3K pathway has just one negative regulator, the phosphatase PTEN, which convert $\mathrm{PIP}_{3}$ in $\mathrm{PIP}_{2}$, inhibiting Akt function (Cully et al., 2006).

This pathway is important in stem niche regulation since is linked to the Wnt one: p-Akt can phosphorylate $\beta$-catenin (He et al., 2007), the main player of Wnt pathway, inducing its nuclear accumulation and enhancing its transcriptional activity (Persad et al., 2001).

It seems indeed to be activated according to a gradient which shows the greater expression in the epithelial cells of the lumen, making guess that it could have a role in confining the effect of the Wnt pathway just in the colon crypts (Kim et al., 2002). 
PI3K deregulation was also noticed in many different human tumours, and it may be attributed to its role in cell survival and proliferation, in particular almost $40 \%$ of human colorectal cancer bring a constitutively PI3K activated pathway, mainly due to PTEN inactivation (Parsons et al., 2005).

\subsubsection{BMP pathway}

BMP pathway is a key regulator of colon cell differentiation (Auclair et al., 2007). BMPs belong to the Transforming Growth Factor beta (TGF- $\beta$ ) super-family members, and after linking their receptor they can trigger different biological processes (Chen et al., 1998). The activation of this pathway leads to the phosphorylation of Smad1, Smad5, and Smad8/R-Smad (Miyazono et al., 2010) that in collaboration with the co-Smad, Smad4, translocate into the nucleus and regulate target gene expression (Derynck and Zhang, 2003).

It was recently demonstrated (Kosinski et al., 2007; Rider and Mulloy, 2010) that there is a fine distribution of the different factors along the crypt: BMP1, BMP2, BMP5, SMAD7, BMP7 and BMP receptors are highly expressed in the apex of the crypt, otherwise BMP antagonist, such as GREM1, GREM2 and chordin-like-1, are expressed at the base of the crypt (Hsu et al., 1998), probably because of the presence of myofibroblasts, which contribute to the stemness maintenance. Interestingly it was shown that BMP pathway can control the number of colon SCs and their self-renewal (He et al., 2004).

There is a strong interaction between BMP with Wnt and PI3K pathway. In particular BMP inhibition by Gremlin leads to the activation of Wnt (Kosinski et al., 2007), as well as BMPs stabilizes PTEN, leading to the Akt activity reduction and thereby reducing $\beta$-catenin intranuclear accumulation (Persad et al., 2001; Waite and Eng, 2003).

\subsubsection{Notch pathway}

The contribution of Notch signaling in colon SCs fate is extensively recognized by the scientific community. Notch pathway consists of four different trans-membrane receptors (Notch1, Notch2, Notch3 and Notch4), and its activation is based on the binding of five different ligands (Jagged-1, Jagged-2, Delta-like 1, Delta like 2 and Delta like 4). The ligands binding induces the cleavage of Notch intracellular domain (NICD) mediated by ADAM metallo-protease. The NICD thus moves to the nucleus where it activates the transcription of all its target genes after dimerization with RBP-jк/CSL (Dikic and Schmidt, 2010; van Es and Clevers, 2005).

The best characterized target gene of Notch pathway is the Hairy/enhancer-of-split (Hes-1) which is involved in the control of proliferation and differentiation (Bray, 2006).

Notch seems to push the proliferation of the transit-amplifying cells compartment, and its activity, in cooperation with specific factors, is fundamental for the differentiation into several epithelial lineages.

Recent studies have shown how Notch and Math1 are essential for colon homeostasis and neoplastic transformation. Moreover, the transgenic expression of the NICD blocks cell differentiation, through the expansion of immature progenitors (Kim and Shivdasani, 2011; van ES et al., 2010).

\subsubsection{Hedgehog pathway}

Sonic hedgehog (Shh) pathway is known to play an important role during colon development. Its activation is mediated by the binding of Shh and Indian hedgehog (Ihh), which are secreted by epithelial cells, to its receptor Patched (PTCH), which is expressed in the sub-epithelial myofibroblasts. The activation leads to the release of the G-coupled protein Smoothened (SMO) that, in collaboration with the GLI transcription factors, migrates into the nucleus to induce target genes activation (Hegde et al., 2008).

The importance of this pathway is not directly the effect on epithelial cell fate, but in the correct development of crypts and villi structures in the mucosa (Madison et al., 2005).

\section{Cancer stem cells}

CSCs concept have been long discussed and investigated in the last years, furthermore also the term CSC was used many times, often changing its meaning. For these reasons, during the Year 2011 Working Conference on CSCs, it was established the correct definition of CSCs opening new questions on this regard (Valent et al., 2012).

It was established that CCSCs arise from the colon SCs, following genetic and/or epigenetic changes, sharing with them several important properties such as the self-renewal and the aberrant multi-lineage differentiation capacity (Barker et al., 2009). CCSCs are often less sensitive to conventional treatments than the bulk of differentiated cells from them generated, and this could be the reason of the initial regression of the tumour, often followed by a more aggressive relapse. Another important aspect in this field is the continuing genomic and epigenomic changes that affect this population, thus contributing to the resistance to standard treatments and then to the amplification of such resistant clones (Baylin and Jones, 2011; Magee et al., 2012; Stratton, 2011). There are two major clinical issues about CSCs that we will try to deepen: the identification and characterization of the CSCs, and the design of new target therapies against them.

The CSCs were isolated and characterized for the first time from acute myeloid leukemia (Bonnet and Dick, 1997; Lapidot et al., 1994), and then this concept has been extended to many solid tumours, including brain (Singh et al., 2004), head and neck (Prince et al., 2007), pancreas (Li et al., 2007a), melanoma (Schatton et al., 2008), liver (Yang et al., 2008), lung (Eramo 


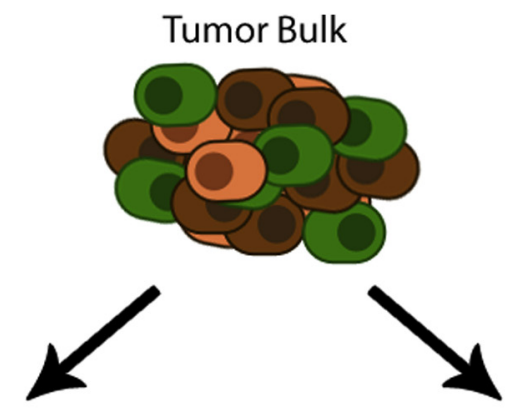

Non tumorigenic cancer cells

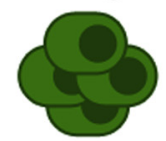

Tumor initiating cells

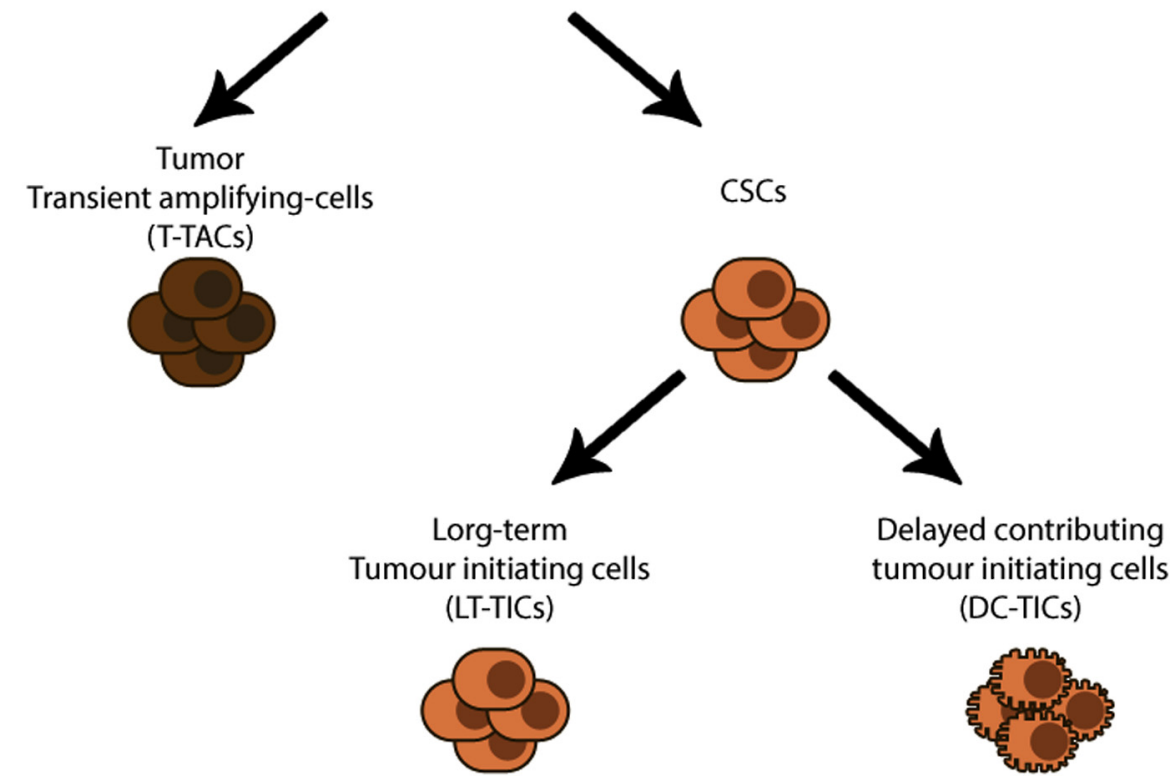

Fig. 1. Heterogeneity of colon tumor initiating cells. Human colon cancer was considered composed by non tumorigenic cells and a small subfraction of tumour-initiating cells (TICs) considered being a functionally homogeneous stem-cell-like population driving tumour growth and metastatic processes. This schema report the recent evidences about cell heterogeneity in TIC compartment, containing three different cell subsets with different biological properties and availability in primary tumour and metastasis. They include T-TACs and CSCs, these last can give rise to LT-TICs and DC-TICs.

et al., 2008), prostate (Collins et al., 2005), ovarian (Curley et al., 2009), and colon cancer (O’Brien et al., 2007; Ricci-Vitiani et al., 2007).

A recent study showed that within the tumour population it is possible to identify not only the CSCs and the differentiated counterpart, but a more heterogeneous population with different biological properties (Dieter et al., 2011 ) Fig. 1.

Using a molecular tracking strategy and exploiting the tumorigenic ability by in vivo transplantation in immune-compromised mice, Dieter et al. (2011) identified three different subtypes of colorectal tumour initiating cells (TICs) with different roles on tumour growth and metastasis formation. The apex of the pyramidal model proposed is constituted by the self renewing long-term TICS (LT-TICS), a cell subset that was founded both in primary and in serial tumours, and delayed contributing TICs (DC-TICs), a cell population that was not detectable in primary tumours (probably due to their quiescent state) but present in subsequent transplants. These two cell populations are identified as CSCs. The third tumour population, the tumour transient-amplifying cells (T-TACs), was characterized by the ability to promote the primary tumour formation, but without being founded in subsequent serial transplants (Fig. 2).

Nevertheless, the molecular mechanisms underlying the biological role of these different cell populations within the tumour are still poorly understood.

\subsection{Colon CSC markers}

Human CCSCs were firstly identified within the CD133 ${ }^{+}$population. CD133, also known as Prominin-1, is a glycoprotein formed by a single polypeptide chain with a molecular weight of about $120 \mathrm{kDa}$ with 20-kDa glycosidic-linked 


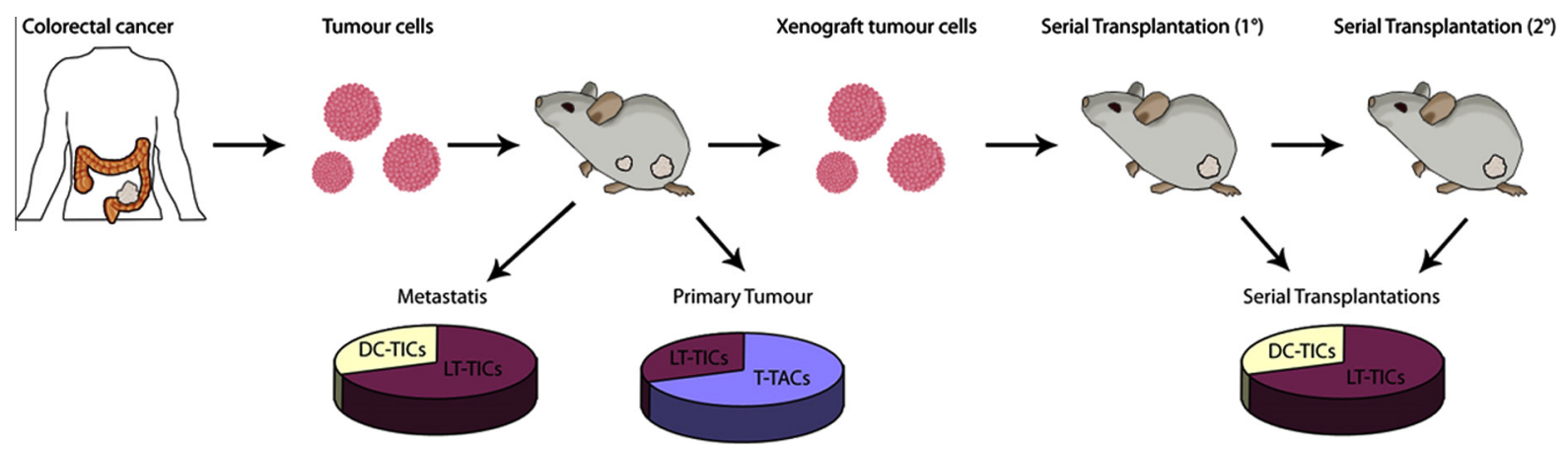

Fig. 2. Biological roles of different subset of TIC during tumour progression. Schematic distribution of colon TICs in xenograft mouse model. Colon tumours contain extensively self-renewing long term TICs (LT-TICs) that are able to maintain tumour formation in serial xenotransplants. Otherwise the tumour transient amplifying cells (T-TACs) possess limited or no self-renewal capacity contributing just to tumour formation in primary mice. Rare delayed contributing TICs (DC-TICs) were found only in secondary or tertiary mice. The metastasis formation seems to be driven by self-renewing LT-TICs demonstrating that tumour initiation, self-renewal, and metastasis formation are limited to different subsets of TICs in primary human colon cancer.

polysaccharides. It is a pentaspan membrane protein, containing five trans-membrane domains, two N-glycosylated extracellular loops, two intracellular domains and a cytoplasmic C-terminal domain (Yin et al., 1997).

Although its function is not yet well known, CD133 may regulate the cell polarity and cell-cell and cell-matrix interactions (Giebel et al., 2004). Ricci-Vitiani et al. (2007) claimed that the $\mathrm{CD}_{133^{+}}$cell fraction is able to form tumour in vivo, maintaining a self-renewal capacity after serial transplantations, otherwise $\mathrm{CD}_{133^{-}}$fraction did not. $\mathrm{CD} 133^{+}$subpopulation was also able to growth as spheres in undifferentiated state, preserving their capacity to differentiate when placed in serum supplemented media.

Although this protein is widely considered to be a marker for the identification of CSCs, its use it is still under debate as demonstrated by several controversial results from different research groups (Shmelkov et al., 2008). Based on this observation it was suggested that CD133 cannot be considered a specific marker for CCSCs since its gene is widely expressed both in undifferentiated and differentiated cells. It was also showed that both $\mathrm{CD} 133^{+}$and $\mathrm{CD} 133^{-}$subpopulations obtained from metastatic colon cancers are able to initiate tumour growth in in vivo transplantation experiments.

This discrepancy could be argued with the different glycosylation status (Kemper et al., 2010) and/or splice variants of CD133 (Fargeas et al., 2004), or with the experimental methodology applied for protein detection, in particular regard cell fixing and/or permeabilization, which could modify the CD133 tertiary structure.

CD44 was recently described as another important marker for CCSCs identification (Du et al., 2008). It is a cell-surface glycoprotein involved in cell-cell interactions, cell adhesion and migration. Moreover, the existence of different splice variants (CD44v) of CD44 has gained a great interest since it was shown for the first time their prominent role to confer a metastatic behavior to tumour cells. Furthermore the role of this molecule in tumour progression was demonstrated in many cancers (Naor et al., 1997; Ponta et al., 2003). CD44 represents a family of glycoproteins encoded by a single gene that undergo to the alternatively splicing giving rise to variable exon products (Screaton et al., 1992). Contrary to the ubiquitous expression of standard isoforms (CD44s), CD44v aberrant expression was observed in many cancer types, conferring them a metastatic potential, resulting in poor prognosis (Harada et al., 2001; Reeder et al., 1998; Wielenga et al., 1993).

CD44 is described as the main receptor of hyaluronan (HA), the most abundant component of the extracellular matrix, highlighting its role as key regulator of cell adhesion (Aruffo et al., 1990). HA binding promotes cell motility and migration, two paramount processes involved on tumour cells dissemination, extravasation of CSCs (Lamontagne and Grandbois, 2008), and metallo-proteases production (Baronas-Lowell et al., 2004).

Finally several cytokines and chemokines such as Interferon gamma (IFN $\gamma$ ) (Levesque and Haynes, 2001), osteopontin (Kazanecki et al., 2007), Hepatocyte Growth Factor (HGF) (Corso et al., 2005), basic Fibroblast Growth Factor (bFGF) (Bennett et al., 1995), Vascular Endothelial Growth Factor (VEGF) (Tremmel et al., 2009), heparin binding factor (Yu et al., 2002), can also bind CD44 with important implications in cell proliferations and survival.

Among the all splice variants of CD44, CD44v6 boast of a central role in metastatic progression and its expression was also associated with poor prognosis in CRC (Peng et al., 2008; Zlobec et al., 2009). CD44v6 is primary involved in the assembly of the matrix, supporting its function in tumour cell cross-talk with the stroma and in pre-metastatic niche formation.

Many other CSC markers have been proposed including CD24 (Choi et al., 2009), ALDH1 (Huang et al., 2009), MSI1 (Potten et al., 2003) and CD29 (Vermeulen et al., 2008). Farther, several studies showed that the CCSCs could reside within different cell subsets, such as in the EpCAM ${ }^{\mathrm{hi}} / \mathrm{CD} 44^{+}$fraction (Dalerba et al., 2007).

However it is common opinion that the cancer stemness is linked not to the exclusive expression of one of these markers but to a combined expression of them. For this reason our group decided to re-examine the expression of these markers: using the single cell sorting we found that the clonogenic potential resided in the CD133+ population which co-expressed the other CCSC markers mentioned above (Vermeulen et al., 2008). 


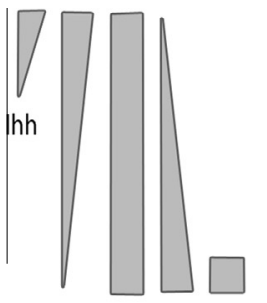

BMP Notch Wnt Noggin

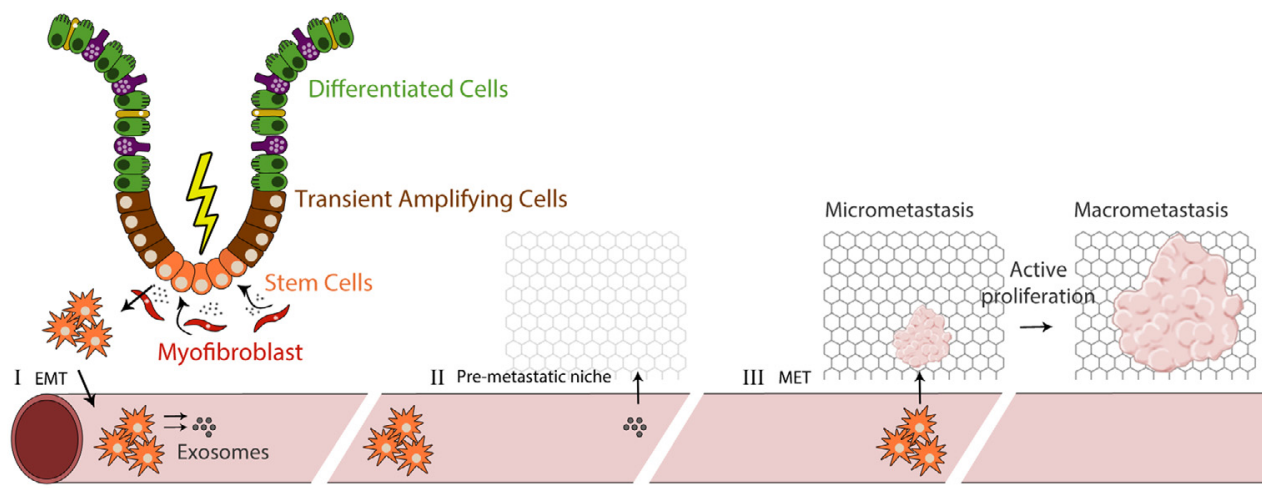

lymphatic/blood vessels

Fig. 3. Colon cancer progression. The formation of metastasis is considered a multistep cell-biological process that involves the dissemination of colon CSCs to anatomically distant organs and the following adaptation and growth in the foreign microenvironment. All these events are driven by the acquisition of genetic and/or epigenetic changes of tumour cells and the cooperation of non-neoplastic stromal cells. The first step consists of the local invasion of colon cancer cell through the EMT. The surviving cancer cells then produce exosomes and other soluble factors that can have an important role in determining the pre-metastatic niche. In the last step the cancer cells have to arrest at the target organ and to become proliferative active through the MET, to finally form clinically detectable macro-metastases.

\subsection{CSCs and pre-metastatic niche}

It is widely accepted that the SCs need a stem cell niche for their maintenance, to control the correct balance between survival, self-renewal and differentiation programs (Morrison and Spradling, 2008).

This concept was also extended to the CSCs population, and convincingly demonstrated mostly during the metastasis formation processes (Bissell and Labarge, 2005).

According to the "seed and soil" theory the organ-preference patterns of tumour metastasis result in interaction between metastatic tumour cells and their specific microenvironment. More recently, it has been suggested that early changes in the microenvironment at the distant sites, could be induced by the primary tumour, reported as "pre-metastatic niche" formation, although the mechanisms and factors responsible for such pre-metastatic niches are not well defined (Kaplan et al., 2005).

Over recent years, there has been an appreciable increase in our understanding of the cross-talk that occurs between these two compartments on the systemic, cellular, and molecular bases. Continued investigations of the mechanisms that mediate site-specific metastasis and new insights to the differences between the normal and CSCs niches will likely lead to the identification of new targets for therapy.

\subsubsection{Exosomes}

As previously mentioned, the CSCs to form metastasis need to be supported by an educated environment necessary to lead extravasation, to implant and grow driven also by soluble factors, recently found likewise within the exosomes which assume on this context a decisive role.

Exosomes are small vesicles of 30-100 nm (Johnstone, 2006) generated upon fusion of multivescicular bodies (MVB) with the plasma membrane (Lakkaraju and Rodriguez-Boulan, 2008), their importance in cancer comes from their biological role and from the evidence that cancer cells release more exosomes than the normal cells (Johnstone, 2006).

The exosomes content is related to their cell of origin, such as the function of the protein there harbored, that is maintained over time (Schorey and Bhatnagar, 2008).

Exosomes contain a big set of both membrane and cytosolic molecules including integrins, ICAM, Major Histocompatibility Complex (MHC) molecules, vesicle transport associated proteins, Heat Shock Proteins (HSPs), signal transduction molecules, and tetraspanins (Gruenberg and Stenmark, 2004). Tetraspanins seem to have a key role in both the mechanisms that regulate the exosomes function, the selective proteins recruitment into exosomes, and the following interaction with the target cells.

Tetraspanins are a family of 34 proteins with four intramembrane domains (Boucheix and Rubinstein, 2001), which form a network with other transmembrane and intracellular signaling proteins (Levy and Shoham, 2005). Among their partners there are G protein coupled receptors (Little et al., 2004), peptidases (Le Naour et al., 2006), Ig superfamily members and, mostly important in CRC, CD44v6 and EpCAM (Kuhn et al., 2007). All these associated partners highlight the tetraspans as an important factor in the regulation of cell motility, adhesion, and invasion.

Furthermore, it has been assed that exosomes hold different mRNAs and miRNAs, which can be in turn transferred to the target cells, thus activating several pathways (Baj-Krzyworzeka et al., 2006). Based on this observation a higher concentration of exosomal mRNAs was indeed found in the serum of CRC patients (Fleischhacker and Schmidt, 2007), enriched in cell-cycle related mRNA leading to endothelial cell proliferation, suggesting their potential involvement in tumour growth 
Table 1

Colon cancer staging.

\begin{tabular}{|c|c|c|c|c|}
\hline AJCC stage & TNM stage & & & TNM stage criteria for colon cancer \\
\hline Stage 0 & Tis & NO & M0 & Tis: tumor confined to mucosa; cancer-in situ \\
\hline Stage I & $\mathrm{T} 1$ & NO & M0 & T1: invasion of submucosa \\
\hline Stage I & $\mathrm{T} 2$ & No & M0 & T1: invasion of muscularis propria \\
\hline Stage II-A & $\mathrm{T} 3$ & NO & M0 & T3: invasion of subserosa or beyond (without other organs involvement) \\
\hline Stage II-B & $\mathrm{T} 4$ & NO & M0 & T4: invasion of adjacent organs or perforation of the visceral peritoneum \\
\hline Stage III-A & $\mathrm{T} 1-2$ & $\mathrm{~N} 1$ & MO & $\mathrm{N} 1$ : metastasis to 1 to 3 regional lymph nodes. $\mathrm{T} 1$ or $\mathrm{T} 2$ \\
\hline Stage III-B & T3-4 & N1 & M0 & $\mathrm{N} 2$ : metastasis to 1 to 3 regional lymph nodes. T3 or T4 \\
\hline Stage III-C & Any $\mathrm{T}$ & N2 & M0 & N2: metastasis to 4 regional lymph nodes. Any T \\
\hline Stage IV & Any $\mathrm{T}$ & Any $\mathrm{N}$ & M1 & M1: distant metastases. Any $\mathrm{T}$, any $\mathrm{N}$ \\
\hline
\end{tabular}

particular refereed to angiogenesis. There are also paramount studies trying to define the miRNA profile in CRC, many of which are down-regulated, suggesting a tumour suppressor role. For this reason improvements on exosomal mRNA and miRNA profile characterization would be suitable to use as prognostic factor (Taylor and Gercel-Taylor, 2008; Tokarz and Blasiak, 2012).

\subsection{EMT and MET in colon cancer progression}

Metastases formation is the final product of a multistep process, which involves the dissemination of cancer cells to distant organs and the following adaptation and proliferation into the foreign tissue microenvironment. This process is determined by the genetic and/or epigenetic alteration of cancer cells, but also driven by non-neoplastic stromal cells (Valastyan and Weinberg, 2011).

The epithelial-mesenchymal transition (EMT) has been noticed as the first step of the metastatic cascade as a well defined biological event playing an important role not only in normal tissue development during the organogenesis, but also in the pathogenesis of diseases, with particular interest during the acquisition of the migratory phenotype of CRC cells (Thiery et al., 2009).

Cells that undergo to EMT are characterized by loss of some epithelial features, such as the apico-basal polarity and cell adhesion, the expression of E-cadherin, occludin and cytokeratins, and at the same time a marked up-regulation of $\mathrm{N}$-cadherin, vimentin, fibronectin, Twist1, zinc-finger proteins (SNAIL, SLUG, ZEB2) and metalloproteinases, with consequent increase of cell mobility (Lee et al., 2006).

A paramount of different signals directly from the surrounding microenvironment may lead to the acquisition of an invasive phenotype in epithelial malignancies (Le et al., 2008), i.e. fibroblasts, myofibroblasts, granulocytes, macrophages and lymphocytes are defined as EMT-inducing factors: pathway as TGF- $\beta$ (through the direct activation of Twist, SLUG and ZEB2), PI3K/Akt (increasing the mTOR kinase expression), Shh and Wnt are indeed potent inducers of EMT (Gulhati et al., 2011; Moustakas and Heldin, 2007).

Furthermore, the mesenchymal-epithelial transition (MET), the reverse process to EMT, is also considered as fundamental mechanism occurring in normal tissue development and in colon mucosa regeneration. This process could play a role both in the first steps of tumour formation, since a dedifferentiation process of the mesenchymal cells is suggested to be crucial in some cancers (Rubio et al., 2008), and in metastasis formation (Brabletz, 2012).

Despite considerable studies in cancer, to date there is not a reliable theory underling the mechanisms regulating the migrating cancer stem cells (mCSCs) (Brabletz et al., 2005) and the acquisition of the metastatic phenotype of tumour cells opening a new issue on tailored therapy Fig. 3.

\section{Treatment option overview}

A key role in the cure of colon cancer is represented by the prevention, followed by the surgery when the tumour is still in the early stages of development. This approach offers to the patients a good rate of success but unfortunately the symptoms of early disease, such as fecal occult blood (FOB), occur just in $5 \%$ of the cases.

Nowadays there are two strategies available for colon cancer screening: the fecal occult blood test (FOBT) and the colonoscopy, these analyses are suggested to be addressed to over-50 years old men and women every 1-2 years.

An important serological marker for early detection and diagnosis for colorectal cancer is the carcinoembryonic antigen (CEA), which can be used in the preoperative staging and postoperative follow-up, even if it possesses a poor predictive value in asymptomatic patients because of the low sensitivity and specificity (Labianca et al., 2010).

Table 1 shows the different colon cancer stages according to the American Joint Committee on Cancer (AJCC) and the TNM Classification of Malignant Tumours (TNM).

Colon cancer staging it is useful for diagnostic and essential to determine the best treatment. As showed in Table 1, the staging depends on the local invasion extension, the degree of lymph node involvement and distant metastasis. For the 
detection of the metastasis it is needed some imaging techniques such as abdominal ultrasound, CT and PET scanning. Of course the definitive classification can only be determined after surgery, and pathology analysis.

The standard treatment for metastatic CRC (only about 39\% of them are found at an early stage) is represented by a combination of 5-fluorouracil, leucovorin and oxaliplatin (FOLFOX), or a combination of 5-fluorouracil, leucovorin and irinotecan (FOLFIRI). These regimens are actually used more frequently in younger than older patients with metastatic CRC, maybe to improve the resection rate (Lenz, 2008).

In order to reduce the risk of relapses, the standard of care for patients with early-stage CRC remains the surgery, combined with adjuvant chemotherapy (most of them are given for about 6 months).

Adjuvant therapy is generally used in cases of high risk, defined by the serosa infiltration of tumour (stages II B, III and IV). Patients with stage II A can be considered at high-risk if there is a poorly differentiated tumour, or more than 12 lymph nodes involved, or with a vascular/lymphatic invasion, or tumour perforation.

The infiltration of tumour cells in regional lymph nodes is today considered as the most accurate prognostic factor for colorectal cancer survival (Iddings and Bilchik, 2007).

CRC staging is useful not only for the prognosis but also to predict which patients will benefit from adjuvant therapy. The chemotherapy administered after surgery at stage III colon cancer patients improves their survival, enhancing both the timeto-recurrence up to $40 \%$ and the overall survival (OS) up to 30\% (Krook et al., 1991; Wolmark et al., 1993).

CCSCs seem to resist death-inducing signals thanks to their slow cycling proliferation and to high levels of drug transporters (Dean et al., 2005). CCSC are also characterized by high levels of anti-apoptotic proteins and it makes them resistant to apoptotic stimuli (Todaro et al., 2008).

After chemo- or radio-treatments, these drug-resistant cells are responsible of the repopulation of treated-tumours, for this reason the identification and targeting of the characteristic pathways of this cell subset, such as of the microenvironment in which they reside could be important to completely eradicate the tumour.

\subsection{Targeted therapy: how to selectively kill CCSCS?}

CCSCs constitute a minority cell subset in the tumour bulk and they are considered to be the source of tumour cell renewal, thus affecting the tumour behavior in terms of cell proliferation and resistance to chemo- and radio-therapy.

Their ability to survive to conventional therapy is due to the over-activation of some signaling pathways (EGFR, VEGF, Wnt, Notch) and to the effect of the microenvironment in which they reside and growth.

For these reasons the molecular targeting of such highly tumorigenic cells must be considered the key to improve the efficacy of current anti-cancer strategies, aiming to sensitize tumours to conventional therapies thus definitely abrogate tumorigenesis.

\subsubsection{CSCs targeting}

Conventional therapies most of the times do not suffice in killing all tumour cells, since they affect the more differentiated cells (which constitute most of the tumour mass) thus saving the CCSCs, which are then able to repopulate the tumour bulk. This is mainly due to the quiescent state of CCSCs that protect them against conventional treatment, which mostly target active proliferating cells.

For this reason one of the most promising treatments that could be coupled to conventional ones is the differentiation therapy. The induction of differentiated state could force the CCSCs to acquire a mature phenotype, thus making them more vulnerable to standard therapies. In this regard Lombardo et al. (2011) have recently demonstrated that BMP4 can promote terminal differentiation, apoptosis, and chemosensitization of CCSCs, suggesting that BMP4 might be considered as a therapeutic agent against CSCs in advanced colorectal tumours.

Since the CCSC state is a consequence of the EMT process, another therapeutic approach could involve the use of EMT inhibitors, by blocking TGF- $\beta$ and Wnt signaling, which are the most characterized pathway known to positively affect this process (De sousa et al., 2011; Thiery et al., 2009).

A recent work revealed that CCSCs (identified as $\mathrm{CD}_{133^{+}}$cells) produce and utilize IL-4 to protect themselves from cell death. Consistently to these data, the treatment with IL-4Ra antagonist or anti-IL-4 neutralizing antibody showed a sensitization of this cell subset to chemotherapeutic agents, paving the way for the development of new CCSCs target treatments (Todaro et al., 2007).

Finally, an important difference between normal and cancer cells is about their metabolism, the so-called Warburg's effect. Warburg et al. (1927) reported an increased uptake of glucose and production of lactate by tumours in vivo as compared with normal tissues.

This study suggests that cancer cells restrict use of fatty-acid oxidation in favor of glycolysis as an ATP energy source and even if this concept was recently revised (Koppenol et al., 2011), it could be exploited for therapy (Dang et al., 2011).

\subsubsection{Targeting CCSCS pathway: VEGF}

It is widely accepted that tumour growth is supported by a framework of new blood vessels, in a process called angiogenesis, which does not occur in the normal healthy tissues except for tissue repair, remodeling or inflammation (Kerbel, 2008). 
Recent findings propose CSCs as strong promoters of angiogenesis, a multistep mechanism that leads to the formation of new or extended capillaries, involving many processes such as vasodilation, vessel permeability, and endothelial cell proliferation and migration.

The interplay between CSCs and vasculature was clearly demonstrated by Bao et al. (2006). In this study it is shown how the $\mathrm{CD} 133^{+}$cells give rise to strongly angiogenic tumours compared to CD133- cell subset. This effect can be explained by a 10-20-fold increase in VEGF release of these cells of $\mathrm{CD} 133^{+}$, giving them a significant angiogenic advantage.

The correlation between CSCs and tumour vascularization was also demonstrated by Folkins et al. (2009), who showed that CSC-high tumours exhibited increased microvessel density and blood perfusion compared with CSC-low ones, also inducing increased mobilization and tumour recruitment of bone marrow-derived endothelial progenitor cells (EPC).

Recent findings showed that also the endothelial cells have an effect on CCSCs. Lu et al. (2013) indeed described how the endothelial cells through paracrine signaling can induce colorectal cancer cells to acquire CSCs properties, in terms of $\mathrm{CD}_{133^{+}} / \mathrm{ALDH}^{+}$compartment and sphere forming capacity, and that this conversion is mainly mediated by Notch pathway.

Together these data suggest that CSCs can be the most important source of angiogenic factors in tumour microenvironment and that the targeting of pro-angiogenic factors could be critical for patient therapy.

In this regard a recent work by Blansfield et al. (2008) showed that the targeting of tumour microenvironment, in particular toward endothelial cells and inhibition of angiogenesis, could be considered a promising therapy to apply in clinic. In this work it was demonstrated how lenalidomide, sunitinib (both involved in inhibition of angiogenesis, through different mechanisms) and cyclophosphamide (cytotoxic to endothelial cells) were able to inhibit the proliferation of endothelial cells in vitro (in an additive manner) and to completely inhibit the in vivo growth of primary tumour in mouse models. Tumour growth inhibition is due to the ability of these compounds to establish an inhospitable tumour microenvironment (Blansfield et al., 2008).

Among molecules that regulate tumour angiogenesis, the most characterized pathway involves VEGFs and receptors (VEGFRs), even if it can be also regulated by many other factors as platelet-derived growth factor (PDGF), FGF and transforming growth factor alpha (TGF- $\alpha$ ) (Hicklin and Ellis, 2005).

The VEGF family encloses six members: the most important is VEGF-A, then the placenta growth factor-1 and -2 (PGF-1, PGF-2), VEGF-B, VEGF-C and VEGF-D. All these molecules are soluble factors secreted by tumour and stromal cells that binding the extracellular domain of their receptors leading to several intracellular signaling cascades endowed with survival, proliferation, migration, differentiation and permeability of endothelial cells.

It was assessed that the VEGF expression may play an important role in human colon cancer progression, in particular during the transition from premalignant adenoma to invasive and metastatic disease (Takahashi et al., 2003). Its overexpression it is correlated with tumour progression and a worse prognosis (Lee et al., 2000).

Judah Folkman in 1971 for the first time proposed a possible key role of angiogenesis in tumours, farther suggesting the anti-angiogenic agents as potential compound for cancer treatment (Folkman, 1971).

Many molecules have been tested and undergone to clinical trials, and among these the bevacizumab, a monoclonal antibody directed against VEGF-A was the first successfully accepted, in 2004, to use in combination with standard chemotherapy for metastatic CRC inhibiting angiogenesis and thus the tumour growth (Gordon et al., 2001).

It is also functional in normalizing the tumour blood vessels structure, decreasing the intra-tumour hydrostatic pressure, enhancing the drug delivery to the tumour (Ellis, 2006).

The bevacizumab was initially use in combination to the IFL (irinotecan, 5-FU and leucovorin) (Hurwitz et al., 2004), and then to other regimens, in many of which it resulted fundamental for increased response rates (RR) and survival rate (Grothey et al., 2008).

Two studies also analyzed its possible negative effect on postoperative wound healing in patients were subjected to hepatic resection, both demonstrating no increase complications upon patients treatment (Gruenberger et al., 2008; Kesmodel et al., 2008).

Unfortunately some important side effects were observed, such as gastrointestinal perforation (1.5\%), arterial thrombosis, myocardial infections and strokes (Prat et al., 2007).

Even if the inhibition of angiogenesis has been emerging as an efficient strategy for treating CRC, recurrences often occur after the first period of suppression of tumour growth. Moreover some anti-angiogenesis drugs have been shown to positively influence metastasis of malignant progression in animal models (Ebos et al., 2009; Pàez-Ribes et al., 2009).

In a recent study it was shown that CCSCs (CD133 ${ }^{+}$cells) are more resistant to anti-angiogenesis treatments, and this could be the reason of the occurring of recurrences after this treatment. This phenomenon is mediated by the activation of anti-apoptotic signaling pathway involving Hsp27, and its inactivation can sensitize CCSCs to undergo cell death (Lin et al., 2013).

\subsubsection{Targeting CCSCs pathway: EGF}

As previously mentioned the CCSCs require the presence of growth factors produced by the microenvironment for their proliferation and maintenance of stem-like properties (Vermeulen et al., 2010). One of the best characterized factors that affect CCSCs behavior is the Epidermal Growth Factor (EGF), which is known to regulate intestinal epithelial cell and stem/progenitor cell growth and differentiation (Suzuki et al., 2010). In a recent study Feng et al. (2012) showed that EGF signaling activation is necessary to promote the formation of CCSCs and for their maintenance of self-renewal capacity. For these reasons EGF receptor (EGFR) became an important possible target in cancer therapy. 
EGFR is a tyrosine kinase receptor belonging to the HER family that includes EGFR itself (Erb1/HER1), Erb2 (HER2/neu), Erb3 (HER3) and Erb4 (HER4). Upon activation by binding of its growth factor ligands EGF and TGF- $\alpha$, EGFR switch from an inactive monomeric form to an active homo- or hetero-dimeric complex resulting in the stimulation of its intrinsic intracellular protein-tyrosine kinase activity, determining an auto-phosphorylation of several tyrosine residues in the C-terminal domain. Receptor activation, through the docking of cytoplasmic proteins, can initiate several cell signaling pathways, including the Ras-Raf-MAPK, PI3K/Akt, the protein kinase C, STAT and src kinase pathway, primarily involved in cell proliferation, inhibition of apoptosis, invasion and migration.

Nowadays, two different anti-EGFR therapies are currently use for colorectal cancer treatment, the Cetuximab, a monoclonal antibodies that recognize EGFR (a partially humanized monoclonal antibody) (Van Cutsem et al., 2009), or panitumumab (a fully human monoclonal antibody) (André et al., 2013), and small molecule inhibitors of EGFR tyrosine kinase activity (TKIs) (Marshall, 2006).

The monoclonal antibody cetuximab prevents receptor activation interfering with its dimerization through steric inhibition of the extracellular domain, leading also to receptor internalization and subsequent degradation. Moreover cetuximab can kill target cells by mediating antibody-dependent cell- mediated cytotoxicity (ADCC) and complement fixation (El Zouhairi et al., 2011).

On the contrary panitumumab blocks ligands binding determining receptor internalization, but without induced degradation, suggesting that it could be recycled to the cell surface.

cetuximab was approved by the US Food and Drug Administration (FDA) in February 2004, in combination with irinotecan in irinotecan-refractory patients, or as a single agent in patients intolerant to irinotecan. It was tested both alone in patients that were refractory to irinotecan-containing regimens, inducing a response in $10.8 \%$ of them with a media time to progression (TPP) of 1.5 months, and in combination with irinotecan, obtaining $22.9 \%$ of response and a TPP of 4.1 months (Cunningham et al., 2004).

Panitumumab obtained the FDA approval based on similar studies, reporting an $8 \%$ of response in patients whose disease had progresses after FOLFOX and FOLFIRI regimens (Douillard et al., 2010; Gibson et al., 2006; Peeters et al., 2010; Van Cutsem et al., 2007).

The more investigated TKIs targeting EGFR for metastatic CRC are gefitinib, erlotinib, and EKB-569. Their activity in metastatic CRC was minimal, and in combination with FOLFOX and FOLFIRI the clinical response rate ranged from $24 \%$ to $74 \%$ in phase II studies. The worse aspects in the use of TIKs were the adverse effects, with a 3-4-fold increase grade of toxicity.

Probably the most interesting aspect of the anti-EGFR therapies is the role of mutant Kras in predicting response to these treatments. Kras is a small intra-membrane serine-threonine kinase, activated just downstream of EGFR, which acts propagating further signaling events.

Retrospective studies for both cetuximab and panitumumab, showed that there is a strong correlation between Kras status and the response to these treatments. Lièvre et al. (2008) demonstrated for cetuximab treatment that in the mutated Kras tumours the response rate was of $0 \%$ versus the $40 \%$ in the tumours with wild-type Kras, with an increased overall survival of 4 months in the latter (Lièvre et al., 2008).

A similar study was performed for panitumumab treatment, where the researchers showed that no mutated Kras tumours responded to panitumumab, versus the $17 \%$ of responding patients with wild-type Kras (Amado et al., 2008).

As a consequence of these findings all the clinical trials for anti-EGFR treatments have to take in consideration the mutational status of Kras.

\section{Immune system, tissue homeostasis and colon cancer development}

The main role of the immune system is to maintain the tissue homeostasis, to protect against pathogens and to eliminate damaged cells.

In this context the tumour is a disease that arises from DNA mutations affecting crucial pathways that regulate cell proliferation, survival and cell death, impairing the tissue homeostasis. The aberrant tissue homeostasis was recently addressed as new field of study drawing complicate and multifunctional network between the microenvironment and tumour cells, in favor of the survival of the latter. Based on this observation the immune microenvironment could play a key role during the tumour progression.

The mammalian immune system is made up of different cell types (innate or adaptive immunity) and mediators, which interact with non-immune cells to create a dynamic network of signals thus providing protection against pathogens, while ensuring tolerance to the self-antigens.

The first-line of protection against perturbations in tissue homeostasis is represented by sentinel macrophages and mast cells which through the release of soluble mediators, such as cytokines, chemokines, matrix remodeling proteases and reactive oxygen species (ROS), attract additional leukocytes into the damaged area.

The dendritic cells (DCs) interconnect directly the innate and the adaptive immunity capturing the foreign antigens and presenting them to the adaptive immune cells into lymphoid organs. Also the natural killer cells (NKs) partecipate to the cross-talking between innate and adaptive immune cells interacting with the DCs, eliminating them or promoting their maturation (Hamerman et al., 2005; Raulet, 2004). 


\section{$\longrightarrow$ Tumor progression}
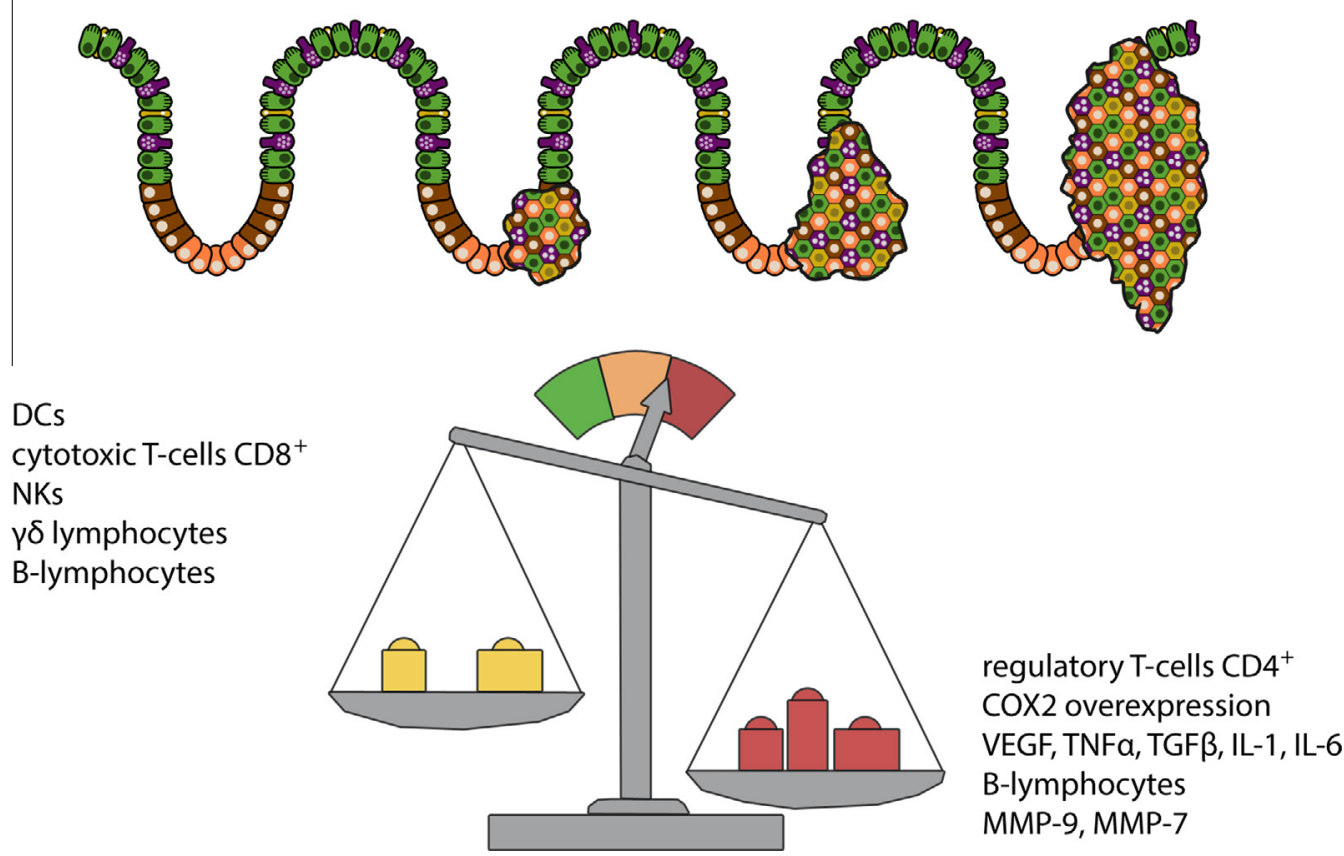

Fig. 4. Dual roles of innate and adaptive immune-cells and their released factors in colon cancer development and progression. The immune system possesses dual and controversial role regard cancer progression and the final result of its function seems to be caused by the correct balance of all its components. When cancer cells are recognized by the immune system the antigens that are present in early neoplastic cells are transported by dendritic cells (DCs) to lymphoid organs where they lead to the activation of adaptive immune cells, thus resulting in both promoting and counteracting tumour growth. The activation of B cells results in chronic activation of innate immune cells in neoplastic tissue thus promoting cell-cycle progression and survival due to the activation of mast cells, granulocytes and macrophages and the factors from them released. Moreover the tumour microenvironment is enriched in pro-inflammatory cytokines, chemokines, extracellular proteases and pro-angiogenic factors, such as TNF $\alpha$, TGF $\beta$, VEGF, interleukin 1 (IL-1) and 6 (IL-6) that contribute to neoplastic cell proliferation and survival. By contrast the activation of adaptive immunity leads to an antitumor effect through T-cell-mediated toxicity in addition to antibody-dependent cell-mediated cytotoxicity and antibody-induced complement-mediated lysis.

Once pathogens have been eliminated, the immune system cells are regulated in terms of proliferation and cell death to restore the normal levels of guard. Unbalance in the immune cells number in a particular district or tissue can dramatically affect the maintenance of tissue homeostasis, such as occurs during tumor formation (Finch and Crimmins, 2004).

The existence of a link between immune cells and cancer has been known for many years (Balkwill and Mantovani, 2001), even if their properly role is not well defined.

Initially it was suggested that the infiltrate leukocyte could have a role in preventing the tumour growth, given the fact that excessive infiltration of NKs in gastric and colorectal cancer was associated with favorable prognosis (Coca et al., 1997; Ishigami et al., 2000). On the contrary the presence of other innate-immune cells within the tumour tissues such as macrophages in breast carcinoma, and mast cells in lung adenocarcinoma and melanoma, were associated with poor clinical prognosis (Leek et al., 1996; Imada et al., 2000; Ribatti et al., 2003).

When colon tissue homeostasis is perturbed, several processes involved in the inflammation are induced, and if this phenomenon is prolonged, so becoming chronic, it can bring to an excessive tissue remodeling, loss of its architecture or completely destruction, as well as induce DNA and protein damages because of the oxidative stress, intensifying the risk of cancer.

The most prominent clinical evidence of a link between chronic inflammation and cancer arises from some epidemiological studies, which claimed that long-term usage of anti-inflammatory drugs, such as aspirin and cyclooxygenase-2 (COX-2) inhibitors, significantly reduce the risk to get a cancer (Dannenberg and Subbaramaiah, 2003), including colorectal one (Rahme et al., 2003).

The inhibition of COX2, involved in the production of prostaglandin, seems to reduce cancer risk according to recent epidemiological studies (Zha et al., 2004). In several human epithelial cancers the COX2 over-expression, mainly found in stromal cells, correlates with poor prognosis (Dannenberg and Subbaramaiah, 2003). The exact mechanism of action of the COX2 inhibitors is not yet entirely clear, but it seems to function by normalizing different pathways of stromal and innate immune cells. 
A possible explanation of why the inflammatory process protects tumour growth instead of counteracts it, comes from the evidence of different profiles of immune status between healthy subjects and cancer affected patients. The latter exhibit an enrichment in regulatory T-cells, at the expense of tumour-killing CD8 ${ }^{+}$CTL (Curiel et al., 2004). Neoplastic microenvironments indeed seem to promote a chronic pro-tumorigenic inflammatory states rather than acute anti-tumour responses (Zou, 2005).

Last but not least the tumour microenvironment is enriched in cytokines, chemokines, metalloproteinases and pro-angiogenic factors, such as Tumour Necrosis Factor alfa (TNF $\alpha$ ), TGF $\beta$, VEGF, interleukin 1 (IL-1) and 6 (IL-6), which contribute to neoplastic cell proliferation and survival of damaged epithelial cells (Balkwill et al., 2005). In this context the matrix metalloproteinases (MMPs) play an important role, due to their capacity to remodel the ECM components and interfering with the cell-cell and cell-matrix adhesions. Despite some MMPs are produced by epithelial cells, the major source of their production are the stromal cell, such as fibroblasts, vascular cells but also immune cells (Egeblad and Werb, 2002). MMP-9 and MMP-7 are the two major proteins of this family having a role in regulation of inflammation and tumour angiogenesis (Bergers et al., 2000; Lynch et al., 2005) Fig. 4.

\subsection{Immunotherapy}

All this advances carried out in recent years has fuelled many researcher group the purpose of developing new approaches of immunotherapy against tumours. The term "immunotherapy" indicates a treatment that includes the induction and enhancement (immunotherapies), or the suppression of immune response (suppression immunotherapies).

Adoptive cell transfer (ACT) approach, involving the transfer of ex vivo expanded autologous or allogeneic tumour reactive lymphocytes, has been reported to induce therapeutic efficacy and increased patients survival when combined with cytotoxic treatments (CTX, chemotherapy and radiotherapy). Ramakrishnan et al. demonstrated that CTX makes tumour cells more susceptible to the cytolytic effect of cytotoxic T lymphocytes (CTLs), and that they are able to induce apoptosis also in neighboring tumour cells that do not express specific tumour antigens (Ramakrishnan et al., 2010). These data suggest that also a small numbers of CTLs could lead to a strong antitumor effect if combined with CTX.

Another important approach in tumour immunotherapy was sprouted from the idea to immunize patients against their own cancer using tumour killed cells, proteins, peptides, or DNA vaccines, even if the success was limited (Amato et al., 2010; Dougan and Dranoff, 2009; Giaccone et al., 2005; Testori et al., 2008).

As already mentioned the DCs are considered a bridge between innate and adaptive immunity. Early clinical trials showed that the vaccination with ex vivo generated DCs pulsed with tumour antigens can be useful even if the clinical benefit was observed only in a small percentage of stage IV patients (Palucka et al., 2008). In some cases of soft tissue sarcoma, the intratumoral treatment with DCs led to an increase in T-cell infiltration (Finkelstein et al., 2012), suggesting that the combined vaccines of DCs and CTX can counteract its immunosuppression effect on tumour microenvironment.

$\mathrm{T}_{\text {regs }}$ targeting in combination with CTX could be very important advance in cancer treatment, since it is known that enrichment of these cells into tumour microenvironment leads to block the anti-tumour immunity response, promoting also malignant proliferation and dissemination of cell through the expression of soluble mediators (Múzes et al., 2012). One of the most efficient strategies is based on CTL-4 inhibition. CTL-4 is a negative co-stimulatory molecule expressed on both T cells and $\mathrm{T}_{\text {regs }}$ and it acts inhibiting $\mathrm{T}$ cells and at the same time promoting $\mathrm{T}_{\text {regs }}$ function. A monoclonal antibody blocking CTL-4, ipilimumab, was recently recommended for the treatment of advanced malignant melanoma, displaying an extended overall survival, correlating with an increase in T-cell activation and $\mathrm{T}_{\text {regs }}$ inhibition (Hodi et al., 2010) in combination with CTX improved patient survival (Robert et al. 2011).

We have recently assessed that NKs can also play an important role in colon CSC recognition and killing (Tallerico et al., 2013). NKs are potent cytotoxic lymphocytes that can recognize tumour cells, in particular CCSCs. We showed that this different susceptibility is due to a different expression of ligands for NKp30 and NKp44 within the natural cytotoxicity receptor (NCR) group of activating NK receptors. The CCSCs express higher levels of these ligands and at the same time lower levels of MHC class I, known to inhibit NK recognition. This study strengthens the idea of a therapy based on the conventional CTX regimen (most effective on differentiated cells) coupled to NKs cells immunotherapy (specific for CSCs). Moreover it was recently demonstrated that is possible to generate mature and functional NKs from several different human embryonic stem cells (hESCs) and induced pluripotent stem cells (iPSCs). This innovative method could be extended to future studies improving clinical-scale expansion of anti-tumour lymphocytes (Knorr et al., 2013).

Most of the current strategies for immunotherapy aim to stimulation of the adaptive immune system dependent on MHC-restricted $\alpha \beta$ T cells, even if their loss is often observed in cancer cells (Gattinoni et al., 2006; Vesely et al., 2011).

We have recently highlighted the crucial role of $\gamma \delta$ T lymphocytes on anticancer therapy, since they exhibit potent MHC-unrestricted lytic activity against tumour cells (Todaro et al. 2009). In particular, this study emphasized the role of aminobisphosphonates (N-BP), as well as the treatment with zoledronate promoting the activation and proliferation of human $\mathrm{V} \gamma 9 \mathrm{~V} \delta 2$. This subpopulation of $\mathrm{T}$ cells has been detected in the majority of CRC tumour infiltrating lymphocyte. Moreover $\mathrm{V} \gamma 9 \mathrm{~V} \delta 2 \mathrm{~T}$ cells can be obtained from patient blood and ex vivo expanded (Bennouna et al., 2008; Kobayashi et al., 2007), thus retaining their migration efficiency (Viey et al., 2008). Finally the $\gamma \delta$ T transfer concomitant with the injection of bisphosphonates have been proved to be well tolerated and this fosters development of alternative, or better, of adjuvant therapies for treatment of tumour patients, including CRC. 


\section{Individualized therapies}

Despite the improvements in cancer therapies and the application of new "target agents", the outlook for most of the patients is still poor, particularly in advanced solid tumours affected patients.

In the last years thanks to the increased diffusion of instruments for the proteomic and genomic characterization of tissues, it was possible to define different subgroups of patients based on the genetic and biological alterations present into colon tumour (De Sousa et al., 2013; Sadanandam et al., 2013). Each subtype shares similarities to distinct cell types of the normal colon crypt, showing different degrees of stemness and Wnt signaling activity.

These classifications could be useful in clinical practice to predict the best regimen to adopt for each patient.

Another important approach for cancer treatment involves the culturing of freshly purified colon cancer cells to directly test different combination of drugs. The idea to introduce individualized therapy harbored from the possibility to individualize and select a small fraction of primary tumour cells with clonogenic capacity, the CSCs.

Three decades ago Salmon and Hamburger developed a culture method now well known as "clonogenic assay" or "human tumour stem cell assay" (HTCA). This methodological approach allowed to culture single cell suspensions from primary tumour in multilayer soft-agar and to treat the derived clone with specific drug (Salmon et al., 1978) introducing the concept of target therapy.

Based on these observations several clinical trials have been carried out, often with surprising results. Von Hoff et al. (1983) published a first study based on HTCS experimental model as guidance for treatment of 470 patients with 27 different advanced metastatic cancers (Von Hoff et al., 1983). They have found that the RR in the assay-guided therapy was $25 \%$, compared to the $14 \%$ in the empiric treatment group. A second randomized clinical trial was performed on 211 ovarian cancer patients and it showed a higher RR in the assay-guided therapy (22\%) compared to the empiric therapy group (3\%) (Von Hoff et al., 1991). However the selection of chemotherapy treatment based on in vitro drug sensitivity testing is not currently recommended outside the clinical trial setting (Samson et al., 2004; Schrag et al., 2004).

\section{The tumour heterogeneity puzzle}

Despite the considerable progress made up on cancer research field, to date the majority of patients does not seem to take advantage of current therapies. These phenomena could be explained by tumour heterogeneity (Marusyk et al., 2012). The intra-tumoral heterogeneity was first proposed in the 70's and justified by the continuous selection of dominant clones and the differentiation of malignant stem cells, underling tumour progression and resistance to treatments.

The new treatment strategies based on advance technologies, always faster and cheaper, aim to characterize individual tumour types reflecting a precise genomic/proteomic profile and to couple them with the best available treatment.

To stress the heterogeneity concept Gerlinger et al. recently demonstrated that about two thirds of the mutations found in single biopsies of renal cell carcinoma were not uniformly distributed throughout all the sample regions within the same patient's tumour (Gerlinger et al., 2012).

A key role in the maintenance of tumour heterogeneity it is certainly played by the surround microenvironment. According to the evolution principle, cells bringing different mutations should converge towards a common phenotype, able to guarantee the cell growth within the tumour. The variable architecture of a tumour (vascularization, infiltration degree, and connective tissue components) allows the selective growth of cell types carrying different mutations.

Since the majority of cancer-related mortality is due to the metastasis formation, and since most of the therapeutic decisions are based on the primary tumour analysis, should be important to extend the phenotypic and genotypic analysis to the metastatic foci (Stoecklein and Klein, 2010). Indeed, although metastatic lesions are related to primary tumours, sometimes they can also carried additional mutations in functionally important loci completely absent in the primary site (Shah et al., 2009; Yachida et al., 2010).

\section{Conclusions}

In recent years there have been great efforts and have been collected a lot of information about the causes of the onset and progression of CRC, but not always it has been found a direct application in the clinical setting, or sometimes the expected results in patients do not reflect those obtained in vitro or in various stages of clinical trials.

The different cell populations within the tumour mass not only restricted to the primary site, as well as the dual role of the immune system against the tumour during its different evolution stages, and finally the diverse response to the treatment of patients, highlight the urgency to obtain a higher resolution microscopic (molecular) analysis of the disease, without giving up on a macroscopic view of the problem.

The future of cancer care lies surely in the individualized treatment of the disease, this approach requires, however, higher costs and dedicated and specialized staff, nowadays still under progress. It will be also necessary to develop faster and more reliable study models than those currently considered valid for the study of this evil. For all these reasons...please be "patient". 


\section{Acknowledgements}

Special thanks to Daniele Di Franco, Dr. in Informatics, for the creation of all the graphic images here attached; Grants AIRC IG 12819 (to G.S.) and AIRC IG 10254 (to M.T); S.D.F. is a Ph.D. student in the International Ph.D. Program in Immunopharmacology at the University of Palermo.

\section{References}

Adegboyega, P.A., Mifflin, R.C., DiMari, J.F., Saada, J.I., Powell, D.W., 2002. Immunohistochemical study of myofibroblasts in normal colonic mucosa, hyperplastic polyps, and adenomatous colorectal polyps. Arch. Pathol. Lab. Med. 126, 829-836.

Al-Hajj, M., Becker, M.W., Wicha, M., Weissman, I., Clarke, M.F., 2004. Therapeutic implications of cancer stem cells. Curr. Opin. Genet. Dev. 14 (1), $43-47$.

Amado, R.G., Wolf, M., Peeters, M., Van Cutsem, E., Siena, S., Freeman, D.J., Juan, T., Sikorski, R., Suggs, S., Radinsky, R., Patterson, S.D., Chang, D.D., 2008. Wildtype KRAS is required for panitumumab efficacy in patients with metastatic colorectal cancer. J. Clin. Oncol. 26 (10), $1626-1634$.

Amato, R.J., Hawkins, R.E., Kaufman, H.L., Thompson, J.A., Tomczak, P., Szczylik, C., McDonald, M., Eastty, S., Shingler, W.H., de Belin, J., Goonewarden, A.M., Naylor, S., Harrop, R., 2010. Vaccination of metastatic renal cancer patients with MVA-5T4: a randomized, double-blind, placebo-controlled phase III study. Clin. Cancer Res. 16 (22), 5539-5547.

André, T., Blons, H., Mabro, M., Chibaudel, B., Bachet, J.B., Tournigand, C., Bennamoun, M., Artru, P., Nguyen, S., Ebenezer, C., Aissat, N., Cayre, A., PenaultLlorca, F., Laurent-Puig, P., de Gramont, A., Gercor, 2013. Panitumumab combined with irinotecan for patients with KRAS wild-type metastatic colorectal cancer refractory to standard chemotherapy: a GERCOR efficacy, tolerance, and translational molecular study. Ann. Oncol. 24 (2), $412-419$.

Aruffo, A., Stamenkovic, I., Melnick, M., Underhill, C.B., Seed, B., 1990. CD44 is the principal cell surface receptor for hyaluronate. Cell 61 (7), 1303-1313 (29).

Auclair, B.A., Benoit, Y.D., Rivard, N., Mishina, Y., Perreault, N., 2007. Bone morphogenetic protein signaling is essential for terminal differentiation of the intestinal secretory cell lineage. Gastroenterology 133, 887-896.

Baj-Krzyworzeka, M., Szatanek, R., Weglarczyk, K., Baran, J., Urbanowicz, B., Brański, P., Ratajczak, M.Z., Zembala, M., 2006. Tumour-derived microvesicles carry several surface determinants and mRNA of tumour cells and transfer some of these determinants to monocytes. Cancer Immunol. Immunother. 55 (7), 808-818.

Balkwill, F., Mantovani, A., 2001. Inflammation and cancer: back to Virchow? Lancet 357 (9255), 539-545.

Balkwill, F., Charles, K.A., Mantovani, A., 2005. Smoldering and polarized inflammation in the initiation and promotion of malignant disease. Cancer Cell 7 (3), 211-217.

Bao, S., Wu, Q., Sathornsumetee, S., Hao, Y., Li, Z., Hjelmeland, A.B., Shi, Q., McLendon, R.E., Bigner, D.D., Rich, J.N., 2006. Stem cell-like glioma cells promote tumor angiogenesis through vascular endothelial growth factor. Cancer Res. 66 (16), 7843-7848.

Barker, N., van Es, J.H., Kuipers, J., Kujala, P., van den Born, M., Cozijnsen, M., Haegebarth, A., Korving, J., Begthel, H., Peters, P.J., Clevers, H., 2007. Identification of stem cells in small intestine and colon by marker gene Lgr5. Nature 449 (7165), 1003-1007.

Barker, N., Ridgway, R.A., van Es, J.H., van de Wetering, M., Begthel, H., van den Born, M., Danenberg, E., Clarke, A.R., Sansom, O.J., Clevers, H., 2009. Crypt stem cells as the cells-of-origin of intestinal cancer. Nature 457 (7229), 608-611.

Baronas-Lowell, D., Lauer-Fields, J.L., Borgia, J.A., Sferrazza, G.F., Al-Ghoul, M., Minond, D., Fields, G.B., 2004. Differential modulation of human melanoma cell metalloproteinase expression by alpha2beta1 integrin and CD44 triple-helical ligands derived from type IV collagen. J. Biol. Chem. 279 (42), $43503-$ 43513.

Batlle, E., Henderson, J.T., Beghtel, H., van den Born, M.M., Sancho, E., Huls, G., Meeldijk, J., Robertson, J., van de Wetering, M., Pawson, T., Clevers, H., 2002. Beta-catenin and TCF mediate cell positioning in the intestinal epithelium by controlling the expression of EphB/ephrinB. Cell 111 (2), 251-263.

Baylin, S.B., Jones, P.A., 2011. A decade of exploring the cancer epigenome - biological and translational implications. Nat. Rev. Cancer 11 (10), $726-734$.

Bennett, K.L., Jackson, D.G., Simon, J.C., Tanczos, E., Peach, R., Modrell, B., Stamenkovic, I., Plowman, G., Aruffo, A., 1995. CD44 isoforms containing exon V3 are responsible for the presentation of heparin-binding growth factor. J. Cell Biol. 128 (4), 687-698.

Bennouna, J., Bompas, E., Neidhardt, E.M., Rolland, F., Philip, I., Galéa, C., Salot, S., Saiagh, S., Audrain, M., Rimbert, M., Lafaye-de Micheaux, S., Tiollier, J., Négrier, S., 2008. Phase-I study of Innacell gammadelta, an autologous cell-therapy product highly enriched in gamma9delta2 T lymphocytes, in combination with IL-2, in patients with metastatic renal cell carcinoma. Cancer Immunol. Immunother. 57 (11), 1599-1609.

Bergers, G., Brekken, R., McMahon, G., Vu, T.H., Itoh, T., Tamaki, K., Tanzawa, K., Thorpe, P., Itohara, S., Werb, Z., Hanahan, D., 2000. Matrix metalloproteinase9 triggers the angiogenic switch during carcinogenesis. Nat. Cell Biol. 2 (10), 737-744.

Bissell, M.J., Labarge, M.A., 2005. Context, tissue plasticity, and cancer: are tumor stem cells also regulated by the microenvironment? Cancer Cell 7 (1), 17 23.

Blansfield, J.A., Caragacianu, D., Alexander 3rd, H.R., Tangrea, M.A., Morita, S.Y., Lorang, D., Schafer, P., Muller, G., Stirling, D., Royal, R.E., Libutti, S.K., 2008. Combining agents that target the tumor microenvironment improves the efficacy of anticancer therapy. Clin. Cancer Res. 14 (1), $270-280$.

Bonnet, D., Dick, J.E., 1997. Human acute myeloid leukemia is organized as a hierarchy that originates from a primitive hematopoietic cell. Nat. Med. 3 (7), $730-737$.

Booth, C., Potten, C.S., 2000. Gut instincts: thoughts on intestinal epithelial stem cells. J. Clin. Invest. 105 (11), $1493-1499$.

Boucheix, C., Rubinstein, E., 2001. Tetraspanins. Cell. Mol. Life Sci. 58 (9), 1189-1205.

Brabletz, T., 2012. EMT and MET in metastasis: where are the cancer stem cells? Cancer Cell 22 (6), 699-701.

Brabletz, T., Jung, A., Dag, S., Hlubek, F., Kirchner, T., 1999. B-Catenin regulates the expression of the matrix metalloproteinase-7 in human colorectal cancer. Am. J. Pathol. 155, 1033-1038.

Brabletz, T., Jung, A., Spaderna, S., Hlubek, F., Kirchner, T., 2005. Opinion: migrating cancer stem cells - an integrated concept of malignant tumour progression. Nat. Rev. Cancer 5 (9), 744-749.

Bray, S.J., 2006. Notch signalling: a simple pathway becomes complex. Nat. Rev. Mol. Cell Biol. 7, 678-689.

Brittan, M., Wright, N.A., 2002. Gastrointestinal stem cells. J. Pathol. 197 (4), 492-509.

Chang, D.Z., Kumar, V., Ma, Y., Li, K., Kopetz, S., 2009. Individualized therapies in colorectal cancer: KRAS as a marker for response to EGFR-targeted therapy. J. Hematol. Oncol. 22, 2-18.

Chen, D., Ji, X., Harris, M.A., Feng, J.Q., Karsenty, G., Celeste, A.J., Rosen, V., Mundy, G.R., Harris, S.E., 1998. Differential roles for bone morphogenetic protein (BMP) receptor type IB and IA in differentiation andspecification of mesenchymal precursor cells to osteoblast and adipocyte lineages. J. Cell Biol. 142 (1), 295-305.

Cheng, H., Leblond, C.P., 1974. Origin, differentiation and renewal of the four main epithelial cell types in the mouse small intestine. V unitarian theory of the origin of the four epithelial cell types. Am. J. Anat. 141 (4), 537-561.

Choi, D., Lee, H.W., Hur, K.Y., Kim, J.J., Park, G.S., Jang, S.H., Song, Y.S., Jang, K.S., Paik, S.S., 2009. Cancer stem cell markers CD133 and CD24 correlate with invasiveness and differentiation in colorectal adenocarcinoma. World J. Gastroenterol. 15 (18), $2258-2264$.

Clarke, M.F., Dick, J.E., Dirks, P.B., Eaves, C.J., Jamieson, C.H., Jones, D.L., Visvader, J., Weissman, I.L., Wahl, G.M., 2006. Cancer stem cells-perspectives on current status and future directions: AACR Workshop on cancer stem cells. Cancer Res. 66 (19), 9339-9344.

Clevers, H., 2006. Wnt/beta-catenin signaling in development and disease. Cell 127 (3), 469-480.

Coca, S., Perez-Piqueras, J., Martinez, D., Colmenarejo, A., Saez, M.A., Vallejo, C., Martos, J.A., Moreno, M., 1997. The prognostic significance of intratumoral natural killer cells in patients with colorectal carcinoma. Cancer 79 (12), 2320-2328. 
Collins, A.T., Berry, P.A., Hyde, C., Stower, M.J., Maitland, N.J., 2005. Prospective identification of tumorigenic prostate cancer stem cells. Cancer Res. 65 (23), 10946-10951.

Corso, S., Comoglio, P.M., Giordano, S., 2005. Cancer therapy: can the challenge be MET? Trends Mol. Med. 11 (6), $284-292$.

Crawford, H.C., Fingleton, B.M., Rudolph-Owen, L.A., Goss, K.J., Rubinfeld, B., Polakis, P., Matrisian, L.M., 1999. The metalloproteinase matrilysin is a target of beta-catenin transactivation in intestinal tumors. Oncogene 18 (18), 2883-2891.

Croker, A.K., Allan, A.L., 2008. Cancer stem cells: implications for the progression and treatment of metastatic disease. J. Cell Mol. Med. 12 (2), 374-390.

Cully, M., You, H., Levine, A.J., Mak, T.W., 2006. Beyond PTEN mutations: the PI3K pathway as an integrator of multiple inputs during tumorigenesis. Nat. Rev. Cancer 6, 184-192.

Cunningham, D., Humblet, Y., Siena, S., Khayat, D., Bleiberg, H., Santoro, A., Bets, D., Mueser, M., Harstrick, A., Verslype, C., Chau, I., Van Cutsem, E., 2004. Cetuximab monotherapy and cetuximab plus irinotecan in irinotecan-refractory metastatic colorectal cancer. N. Engl. J. Med. 351 (4), 337 -345.

Curiel, T.J., Coukos, G., Zou, L., Alvarez, X., Cheng, P., Mottram, P., Evdemon-Hogan, M., Conejo-Garcia, J.R., Zhang, L., Burow, M., Zhu, Y., Wei, S., Kryczek, I., Daniel, B., Gordon, A., Myers, L., Lackner, A., Disis, M.L., Knutson, K.L., Chen, L., Zou, W., 2004. Specific recruitment of regulatory T cells in ovarian carcinoma fosters immune privilege and predicts reduced survival. Nat. Med. 10 (9), 942-949.

Curley, M.D., Therrien, V.A., Cummings, C.L., Sergent, P.A., Koulouris, C.R., Friel, A.M., Roberts, D.J., Seiden, M.V., Scadden, D.T., Rueda, B.R., Foster, R., 2009. CD133 expression defines a tumor initiating cell population in primary human ovarian cancer. Stem Cells 27 (12), $2875-2883$.

Dalerba, P., Dylla, S.J., Park, I.K., Liu, R., Wang, X., Cho, R.W., Hoey, T., Gurney, A., Huang, E.H., Simeone, D.M., Shelton, A.A., Parmiani, G., Castelli, C., Clarke, M.F., 2007. Phenotypic characterization of human colorectal cancer stem cells. Proc. Natl. Acad. Sci. USA 104 (24), $10158-10163$.

Dang, C.V., Hamaker, M., Sun, P., Le, A., Gao, P., 2011. Therapeutic targeting of cancer cell metabolism. J. Mol. Med. (Berl) 89 (3), 205-212.

Dannenberg, A.J., Subbaramaiah, K., 2003. Targeting cyclooxygenase-2 in human neoplasia: rationale and promise. Cancer Cell 4 (6), $431-436$.

de Sousa, E.M., Vermeulen, L., Richel, D., Medema, J.P., 2011. Targeting Wnt signaling in colon cancer stem cells. Clin. Cancer Res. 17 (4), 647-653.

De Sousa, E., Melo, F., Wang, X., Jansen, M., Fessler, E., Trinh, A., de Rooij, L.P., de Jong, J.H., de Boer, O.J., van Leersum, R., Bijlsma, M.F., Rodermond, H., van der Heijden, M., van Noesel, C.J., Tuynman, J.B., Dekker, E., Markowetz, F., Medema, J.P., Vermeulen, L., 2013. Poor-prognosis colon cancer is defined by a molecularly distinct subtype and develops from serrated precursor lesions. Nat. Med. 19 (5), 614-618.

Dean, M., Fojo, T., Bates, S., 2005. Tumour stem cells and drug resistance. Nat. Rev. Cancer 5 (4), $275-284$.

Derynck, R., Zhang, Y.E., 2003. Smad-dependent and Smad-independent pathways in TGF-beta family signalling. Nature 425, $577-584$.

Dieter, S.M., Ball, C.R., Hoffmann, C.M., Nowrouzi, A., Herbst, F., Zavidij, O., Abel, U., Arens, A., Weichert, W., Brand, K., Koch, M., Weitz, J., Schmidt, M., von Kalle, C., Glimm, H., 2011. Distinct types of tumor-initiating cells form human colon cancer tumors and metastases. Cell Stem Cell 9 (4), 357-365.

Dikic, I., Schmidt, M.H., 2010. Notch: implications of endogenous inhibitors for therapy. BioEssays 32 (6), $481-487$.

Dougan, M., Dranoff, G., 2009. Immune therapy for cancer. Annu. Rev. Immunol. 27, 83-117.

Douillard, J.Y., Siena, S., Cassidy, J., Tabernero, J., Burkes, R., Barugel, M., Humblet, Y., Bodoky, G., Cunningham, D., Jassem, J., Rivera, F., Kocákova, I., Ruff, P., Błasińska-Morawiec, M., Šmakal, M., Canon, J.L., Rother, M., Oliner, K.S., Wolf, M., Gansert, J., 2010. Randomized, phase III trial of panitumumab with infusional fluorouracil, leucovorin, and oxaliplatin (FOLFOX4) versus FOLFOX4 alone as first-line treatment in patients with previously untreated metastatic colorectal cancer: the PRIME study. J. Clin. Oncol. 28 (31), 4697-4705.

Du, L., Wang, H., He, L., Zhang, J., Ni, B., Wang, X., Jin, H., Cahuzac, N., Mehrpour, M., Lu, Y., Chen, Q., 2008. CD44 is of functional importance for colorectal cancer stem cells. Clin. Cancer Res. 14 (21), 6751-6760.

Ebos, J.M., Lee, C.R., Cruz-Munoz, W., Bjarnason, G.A., Christensen, J.G., Kerbel, R.S., 2009. Accelerated metastasis after short-term treatment with a potent inhibitor of tumor angiogenesis. Cancer Cell 15 (3), 232-239.

Egeblad, M., Werb, Z., 2002. New functions for the matrix metalloproteinases in cancer progression. Nat. Rev. Cancer 2 (3), $161-174$.

El Zouhairi, M., Charabaty, A., Pishvaian, M.J., 2011. Molecularly targeted therapy for metastatic colon cancer: proven treatments and promising new agents. Gastrointest. Cancer Res. 4 (1), 15-21.

Ellis, L.M., 2006. Mechanisms of action of bevacizumab as a component of therapy for metastatic colorectal cancer. Semin. Oncol. 33 (5 Suppl 10), S1-S7.

Eramo, A., Lotti, F., Sette, G., Pilozzi, E., Biffoni, M., Di Virgilio, A., Conticello, C., Ruco, L., Peschle, C., De Maria, R., 2008. Identification and expansion of the tumorigenic lung cancer stem cell population. Cell Death Differ. 15 (3), 504-514.

Fargeas, C.A., Joester, A., Missol-Kolka, E., Hellwig, A., Huttner, W.B., Corbeil, D., 2004. Identification of novel Prominin-1/CD133 splice variants with alternative C-termini and their expression in epididymis and testis. J. Cell Sci. 117 (Pt 18), 4301-4311.

Fearnhead, N.S., Britton, M.P., Bodmer, W.F., 2001. The ABC of APC. Hum. Mol. Genet. 10 (7), 721-733.

Fearon, E.R., Vogelstein, B., 1990. A genetic model for colorectal tumorigenesis. Cell 61 (5), 759-767.

Feng, Y., Dai, X., Li, X., Wang, H., Liu, J., Zhang, J., Du, Y., Xia, L., 2012. EGF signalling pathway regulates colon cancer stem cell proliferation and apoptosis. Cell Prolif. 45 (5), 413-419.

Finch, C.E., Crimmins, E.M., 2004. Inflammatory exposure and historical changes in human life-spans. Science 305 (5691), $1736-1739$.

Finkelstein, S.E., Iclozan, C., Bui, M.M., Cotter, M.J., Ramakrishnan, R., Ahmed, J., Noyes, D.R., Cheong, D., Gonzalez, R.J., Heysek, R.V., Berman, C., Lenox, B.C., Janssen, W., Zager, J.S., Sondak, V.K., Letson, G.D., Antonia, S.J., Gabrilovich, D.I., 2012. Combination of external beam radiotherapy (EBRT) with intratumoral injection of dendritic cells as neo-adjuvant treatment of high-risk soft tissue sarcoma patients. Int. J. Radiat. Oncol. Biol. Phys. 82 (2), 924932.

Fleischhacker, M., Schmidt, B., 2007. Circulating nucleic acids (CNAs) and cancer-a survey. Biochim. Biophys. Acta 1775 (1), $181-232$.

Folkins, C., Shaked, Y., Man, S., Tang, T., Lee, C.R., Zhu, Z., Hoffman, R.M., Kerbel, R.S., 2009. Glioma tumor stem-like cells promote tumor angiogenesis and vasculogenesis via vascular endothelial growth factor and stromal-derived factor 1. Cancer Res. 69 (18), $7243-7251$.

Folkman, J., 1971. Tumor angiogenesis: therapeutic implications. N. Engl. J. Med. 285 (21), 1182-1186.

Galiatsatos, P., Foulkes, W.D., 2006. Familial adenomatous polyposis. Am. J. Gastroenterol. 101 (2), $385-398$.

Gattinoni, L., Powell Jr., D.J., Rosenberg, S.A., Restifo, N.P., 2006. Adoptive immunotherapy for cancer: building on success. Nat. Rev. Immunol. 6 (5), $383-393$.

Gerlinger, M., Rowan, A.J., Horswell, S., Larkin, J., Endesfelder, D., Gronroos, E., Martinez, P., Matthews, N., Stewart, A., Tarpey, P., Varela, I., Phillimore, B., Begum, S., McDonald, N.Q., Butler, A., Jones, D., Raine, K., Latimer, C., Santos, C.R., Nohadani, M., Eklund, A.C., Spencer-Dene, B., Clark, G., Pickering, L., Stamp, G., Gore, M., Szallasi, Z., Downward, J., Futreal, P.A., Swanton, C., 2012. Intratumor heterogeneity and branched evolution revealed by multiregion sequencing. N. Engl. J. Med. 366 (10), 883-892.

Giaccone, G., Debruyne, C., Felip, E., Chapman, P.B., Grant, S.C., Millward, M., Thiberville, L., D’addario, G., Coens, C., Rome, L.S., Zatloukal, P., Masso, O., Legrand, C., 2005. Phase III study of adjuvant vaccination with Bec2/bacille Calmette-Guerin in responding patients with limited-disease small-cell lung cancer (European organisation for research and treatment of cancer 08971-08971B; silva study). J. Clin. Oncol. 23 (28), $6854-6864$.

Gibson, T.B., Ranganathan, A., Grothey, A., 2006. Randomized phase III trial results of panitumumab, a fully human anti-epidermal growth factor receptormonoclonal antibody, in metastatic colorectal cancer. Clin. Colorectal Cancer 6 (1), 29-31.

Giebel, B., Corbeil, D., Beckmann, J., Höhn, J., Freund, D., Giesen, K., Fischer, J., Kögler, G., Wernet, P., 2004. Segregation of lipid raft markers including CD133 in polarized human hematopoieticstem and progenitor cells. Blood 104 (8), 2332-2338.

Gordon, M.S., Margolin, K., Talpaz, M., Sledge Jr., G.W., Holmgren, E., Benjamin, R., Stalter, S., Shak, S., Adelman, D., 2001. Phase I safety and pharmacokinetic study of recombinant human anti-vascular endothelial growth factor in patients with advanced cancer. J. Clin. Oncol. 19 (3), 843-850.

Gregorieff, A., Pinto, D., Begthel, H., Destrée, O., Kielman, M., Clevers, H., 2005. Expression pattern of Wnt signaling components in the adult intestine. Gastroenterology 129 (2), 626-638.

Grivennikov, S.I., Greten, F.R., Karin, M., 2010. Immunity, inflammation, and cancer. Cell 140 (6), $883-899$.

Grothey, A., Sugrue, M.M., Purdie, D.M., Dong, W., Sargent, D., Hedrick, E., Kozloff, M., 2008. Bevacizumab beyond first progression is associated with prolonged overall survival in metastatic colorectal cancer: results from a large observational cohort study (BRiTE). J. Clin. Oncol. 26 (33), 5326-5334.

Gruenberg, J., Stenmark, H., 2004. The biogenesis of multivesicular endosomes. Nat. Rev. Mol. Cell Biol. 5 (4), $317-323$. 
Gruenberger, B., Tamandl, D., Schueller, J., Scheithauer, W., Zielinski, C., Herbst, F., Gruenberger, T., 2008. Bevacizumab, capecitabine, and oxaliplatin as neoadjuvant therapy for patients with potentially curable metastaticcolorectal cancer. J. Clin. Oncol. 26 (11), $1830-1835$.

Gulhati, P., Bowen, K.A., Liu, J., Stevens, P.D., Rychahou, P.G., Chen, M., Lee, E.Y., Weiss, H.L., O'Connor, K.L., Gao, T., Evers, B.M., 2011. MTORC1 and mTORC2 regulate EMT, motility, and metastasis of colorectal cancer via RhoA and Rac1 signaling pathways. Cancer Res. 71 (9), $3246-3256$.

Hamerman, J.A., Ogasawara, K., Lanier, L.L., 2005. NK cells in innate immunity. Curr. Opin. Immunol. 17 (1), $29-35$.

Harada, N., Mizoi, T., Kinouchi, M., Hoshi, K., Ishii, S., Shiiba, K., Sasaki, I., Matsuno, S., 2001. Introduction of antisense CD44S CDNA down-regulates expression of overall CD44 isoforms and inhibits tumor growth and metastasis in highly metastatic colon carcinoma cells. Int. J. Cancer 91 (1), 67-75.

He, T.C., Sparks, A.B., Rago, C., Hermeking, H., Zawel, L., da Costa, L.T., Morin, P.J., Vogelstein, B., Kinzler, K.W., 1998. Identification of c-MYC as a target of the APC pathway. Science 281 (5382), 1509-1512.

He, X.C., Zhang, J., Tong, W.G., Tawfik, O., Ross, J., Scoville, D.H., Tian, Q., Zeng, X., He, X., Wiedemann, L.M., Mishina, Y., Li, L., 2004. BMP signaling inhibits intestinal stem cell self-renewal through suppression of Wnt-beta-cateninsignaling. Nat. Genet. 36 (10), 1117-1121.

He, X.C., Yin, T., Grindley, J.C., Tian, Q., Sato, T., Tao, W.A., Dirisina, R., Porter-Westpfahl, K.S., Hembree, M., Johnson, T., Wiedemann, L.M., Barrett, T.A., Hood, L., Wu, H., Li, L., 2007. PTEN-deficient intestinal stem cells initiate intestinal polyposis. Nat. Genet. 39 (2), 189-198.

Hegde, G.V., Munger, C.M., Emanuel, K., Joshi, A.D., Greiner, T.C., Weisenburger, D.D., Vose, J.M., Joshi, S.S., 2008. Targeting of sonic hedgehog-GLI signaling: a potential strategy to improve therapy for mantle celllymphoma. Mol. Cancer Ther. 7 (6), 1450-1460.

Heppner, G.H., 1984. Tumor heterogeneity. Cancer Res. 44 (6), 2259-2265.

Hicklin, D.J., Ellis, L.M., 2005. Role of the vascular endothelial growth factor pathway in tumor growth and angiogenesis. J. Clin. Oncol. 23 (5), $1011-1027$.

Hlubek, F., Jung, A., Kotzor, N., Kirchner, T., Brabletz, T., 2001. Expression of the invasion factor laminin $\gamma 2$ in colorectal carcinomas is regulated by $\beta$-catenin. Cancer Res. 61, 8089-8093.

Hodi, F.S., O’Day, S.J., McDermott, D.F., Weber, R.W., Sosman, J.A., Haanen, J.B., Gonzalez, R., Robert, C., Schadendorf, D., Hassel, J.C., Akerley, W., van den Eertwegh, A.J., Lutzky, J., Lorigan, P., Vaubel, J.M., Linette, G.P., Hogg, D., Ottensmeier, C.H., Lebbé, C., Peschel, C., Quirt, I., Clark, J.I., Wolchok, J.D., Weber, J.S., Tian, J., Yellin, M.J., Nichol, G.M., Hoos, A., Urba, W.J., 2010. Improved survival with ipilimumab in patients with metastatic melanoma. N. Engl. J. Med. 363 (8), 711-723.

Holmberg, J., Genander, M., Halford, M.M., Annerén, C., Sondell, M., Chumley, M.J., Silvany, R.E., Henkemeyer, M., Frisén, J., 2006. EphB receptors coordinate migration and proliferation in the intestinal stem cell niche. Cell 125 (6), 1151-1163.

Hsu, D.R., Economides, A.N., Wang, X., Eimon, P.M., Harland, R.M., 1998. The Xenopus dorsalizing factor Gremlin identifies a novel family of secreted proteins that antagonize BMP activities. Mol. Cell 1, 673-683.

Huang, E.H., Hynes, M.J., Zhang, T., Ginestier, C., Dontu, G., Appelman, H., Fields, J.Z., Wicha, M.S., Boman, B.M., 2009. Aldehyde dehydrogenase 1 is a marker for normal and malignant human colonic stem cells (SC) and tracks SC overpopulation during colon tumorigenesis. Cancer Res. 69 (8), $3382-3389$.

Hurwitz, H., Fehrenbacher, L., Novotny, W., Cartwright, T., Hainsworth, J., Heim, W., Berlin, J., Baron, A., Griffing, S., Holmgren, E., Ferrara, N., Fyfe, G., Rogers, B., Ross, R., Kabbinavar, F., 2004. Bevacizumab plus irinotecan, fluorouracil, and leucovorin for metastatic colorectal cancer. N. Engl. J. Med. 350 (23), 2335-2342.

Iddings, D., Bilchik, A., 2007. The biologic significance of micrometastatic disease and sentinel lymph node technology on colorectal cancer. J. Surg. Oncol. 96 (8), 671-677.

Imada, A., Shijubo, N., Kojima, H., Abe, S., 2000. Mast cells correlate with angiogenesis and poor outcome in stage I lung adenocarcinoma. Eur. Respir. J. 15 (6), 1087-1093.

Ishigami, S., Natsugoe, S., Tokuda, K., Nakajo, A., Che, X., Iwashige, H., Aridome, K., Hokita, S., Aikou, T., 2000. Prognostic value of intratumoral natural killer cells in gastric carcinoma. Cancer 88 (3), 577-583.

Jänne, P.A., Mayer, R.J., 2000. Chemoprevention of colorectal cancer. N. Engl. J. Med. 342 (26), 1960-1968.

Jemal, A., Bray, F., Center, M.M., Ferlay, J., Ward, E., Forman, D., 2011. Global cancer statistics. CA Cancer J. Clin. 61 (2), 69-90.

Johnstone, R.M., 2006. Exosomes biological significance: a concise review. Blood Cells Mol. Dis. 36 (2), $315-321$.

Kaplan, R.N., Riba, R.D., Zacharoulis, S., Bramley, A.H., Vincent, L., Costa, C., MacDonald, D.D., Jin, D.K., Shido, K., Kerns, S.A., Zhu, Z., Hicklin, D., Wu, Y., Port, J.L., Altorki, N., Port, E.R., Ruggero, D., Shmelkov, S.V., Jensen, K.K., Rafii, S., Lyden, D., 2005. VEGFR1-positive haematopoietic bone marrow progenitors initiate the pre-metastatic niche. Nature 438 (7069), 820-827.

Kazanecki, C.C., Uzwiak, D.J., Denhardt, D.T., 2007. Control of osteopontin signaling and function by post-translational phosphorylation and protein folding. J. Cell. Biochem. 102 (4), 912-924.

Kemper, K., Sprick, M.R., de Bree, M., Scopelliti, A., Vermeulen, L., Hoek, M., Zeilstra, J., Pals, S.T., Mehmet, H., Stassi, G., Medema, J.P., 2010. The AC133 epitope, but not the CD133 protein, is lost upon cancer stem cell differentiation. Cancer Res. 70 (2), $719-729$.

Kerbel, R.S., 2008. Tumor angiogenesis. N. Engl. J. Med. 358 (19), 2039-2049.

Kesmodel, S.B., Ellis, L.M., Lin, E., Chang, G.J., Abdalla, E.K., Kopetz, S., Vauthey, J.N., Rodriguez-Bigas, M.A., Curley, S.A., Feig, B.W., 2008. Preoperative bevacizumab does not significantly increase postoperative complication rates in patients undergoing hepatic surgery for colorectal cancer liver metastases. J. Clin. Oncol. 26 (32), 5254-5260.

Kim, T.H., Shivdasani, R.A., 2011. Genetic evidence that intestinal notch functions vary regionally and operate through a common mechanism of math1 repression. J. Biol. Chem. 286 (13), 11427-11433.

Kim, S., Domon-Dell, C., Wang, Q., Chung, D.H., Di Cristofano, A., Pandolfi, P.P., Freund, J.N., Evers, B.M., 2002. PTEN and TNF-alpha regulation of the intestinal-specific Cdx-2 homeobox gene through a PI3K, PKB/Akt, and NF-kappaB-dependent pathway. Gastroenterology 123 (4), $1163-1178$.

Kinzler, K.W., Vogelstein, B., 1996. Lessons from hereditary colorectal cancer. Cell 87 (2), 159-170.

Kirkland, S.C., 1988. Clonal origin of columnar, mucous, and endocrine cell lineages in human colorectal epithelium. Cancer 61 (7), $1359-1363$.

Knorr, D.A., Ni, Z., Hermanson, D., Hexum, M.K., Bendzick, L., Cooper, L.J., Lee, D.A., Kaufman, D.S., 2013. Clinical-scale derivation of natural killer cells from human pluripotent stem cells for cancer therapy. Stem Cells Transl. Med. 2 (4), 274-283.

Kobayashi, H., Tanaka, Y., Yagi, J., Osaka, Y., Nakazawa, H., Uchiyama, T., Minato, N., Toma, H., 2007. Safety profile and anti-tumor effects of adoptive immunotherapy using gamma-delta T cells against advanced renal cell carcinoma: a pilot study. Cancer Immunol. Immunother. 56 (4), 469-476.

Koppenol, W.H., Bounds, P.L., Dang, C.V., 2011. Otto Warburg's contributions to current concepts of cancer metabolism. Nat. Rev. Cancer 11 (5), 325-337.

Kosinski, C., Li, V.S., Chan, A.S., Zhang, J., Ho, C., Tsui, W.Y., Chan, T.L., Mifflin, R.C., Powell, D.W., Yuen, S.T., Leung, S.Y., Chen, X., 2007. Gene expression patterns of human colon tops and basal crypts and BMP antagonists as intestinal stem cell niche factors. Proc. Natl. Acad. Sci. USA 104 (39), 1541815423.

Krook, J.E., Moertel, C.G., Gunderson, L.L., Wieand, H.S., Collins, R.T., Beart, R.W., Kubista, T.P., Poon, M.A., Meyers, W.C., Mailliard, J.A., Twito, D.I., Morton, R.F., Veeder, M.H., Witzig, T.E., Cha, S., Vidyarthi, S.C., 1991. Effective surgical adjuvant therapy for high-risk rectal carcinoma. N. Engl. J. Med. 324 (11), $709-715$.

Kuhn, S., Koch, M., Nübel, T., Ladwein, M., Antolovic, D., Klingbeil, P., Hildebrand, D., Moldenhauer, G., Langbein, L., Franke, W.W., Weitz, J., Zöller, M., 2007. A complex of EpCAM, claudin-7, CD44 variant isoforms, and tetraspanins promotes colorectal cancer progression. Mol. Cancer Res. 5 (6), $553-567$.

Labianca, R., Nordlinger, B., Beretta, G.D., Brouquet, A., Cervantes, A., ESMO Guidelines Working Group, 2010. Primary colon cancer: ESMO clinical practice guidelines for diagnosis, adjuvant treatment and follow-up. Ann. Oncol. 21 (Suppl 5), 70-77.

Lakkaraju, A., Rodriguez-Boulan, E., 2008. Itinerant exosomes: emerging roles in cell and tissue polarity. Trends Cell Biol. 18 (5), $199-209$.

Lamontagne, C.A., Grandbois, M., 2008. PKC-induced stiffening of hyaluronan/CD44 linkage; local force measurements on glioma cells. Exp. Cell Res. 314 (2), $227-236$.

Lapidot, T., Sirard, C., Vormoor, J., Murdoch, B., Hoang, T., Caceres-Cortes, J., Minden, M., Paterson, B., Caligiuri, M.A., Dick, J.E., 1994. A cell initiating human acute myeloid leukaemia after transplantation into SCID mice. Nature 367 (6464), 645-648. 
Le, N.H., Franken, P., Fodde, R., 2008. Tumour-stroma interactions in colorectal cancer: converging on beta-catenin activation and cancer stemness. Br. J. Cancer 98 (12), 1886-1893.

Le Naour, F., André, M., Boucheix, C., Rubinstein, E., 2006. Membrane microdomains and proteomics: lessons from tetraspanin microdomains and comparison with lipidrafts. Proteomics 6 (24), 6447-6454.

Lee, J.C., Chow, N.H., Wang, S.T., Huang, S.M., 2000. Prognostic value of vascular endothelial growth factor expression in colorectal cancer patients. Eur. J. Cancer 36 (6), 748-753.

Lee, J.M., Dedhar, S., Kalluri, R., Thompson, E.W., 2006. The epithelial-mesenchymal transition: new insights in signaling, development, and disease. J. Cell Biol. 172 (7), 973-981.

Leek, R.D., Lewis, C.E., Whitehouse, R., Greenall, M., Clarke, J., Harris, A.L., 1996. Association of macrophage infiltration with angiogenesis and prognosis in invasive breast carcinoma. Cancer Res. 56 (20), 4625-4629.

Lenz, H.J., 2008. First-line combination treatment of colorectal cancer with hepatic metastases: choosing a targeted agent. Cancer Treat. Rev. 34 (Suppl. 2), S3-S7.

Levesque, M.C., Haynes, B.F., 2001. Activated T lymphocytes regulate hyaluronan binding to monocyte CD44 via production of IL-2 and IFN-gamma. J. Immunol. 166 (1), 188-196.

Levy, S., Shoham, T., 2005. Protein-protein interactions in the tetraspanin web. Physiology (Bethesda) 20, $218-224$.

Li, C., Heidt, D.G., Dalerba, P., Burant, C.F., Zhang, L., Adsay, V., Wicha, M., Clarke, M.F., Simeone, D.M., 2007a. Identification of pancreatic cancer stem cells. Cancer Res. 67 (3), 1030-1037.

Li, F., Tiede, B., Massagué, J., Kang, Y., 2007b. Beyond tumorigenesis: cancer stem cells in metastasis. Cell Res. 17 (1), 3-14.

Lièvre, A., Bachet, J.B., Boige, V., Cayre, A., Le Corre, D., Buc, E., Ychou, M., Bouché, O., Landi, B., Louvet, C., André, T., Bibeau, F., Diebold, M.D., Rougier, P., Ducreux, M., Tomasic, G., Emile, J.F., Penault-Llorca, F., Laurent-Puig, P., 2008. KRAS mutations as an independent prognostic factor in patients with advanced colorectal cancer treated with cetuximab. J. Clin. Oncol. 26 (3), 374-379.

Lin, S.P., Lee, Y.T., Yang, S.H., Miller, S.A., Chiou, S.H., Hung, M.C., Hung, S.C., 2013. Colon cancer stem cells resist antiangiogenesis therapy-induced apoptosis. Cancer Lett. 328 (2), 226-234.

Little, K.D., Hemler, M.E., Stipp, C.S., 2004. Dynamic regulation of a GPCR-tetraspanin-G protein complex on intact cells: central role of CD81 in facilitating GPR56-Galpha q/11 association. Mol. Biol. Cell 15 (5), 2375-2387.

Lobo, N.A., Shimono, Y., Qian, D., Clarke, M.F., 2007. The biology of cancer stem cells. Annu. Rev. Cell Dev. Biol. 23, 675-699.

Lombardo, Y., Scopelliti, A., Cammareri, P., Todaro, M., Iovino, F., Ricci-Vitiani, L., Gulotta, G., Dieli, F., de Maria, R., Stassi, G., 2011. Bone morphogenetic protein 4 induces differentiation of colorectal cancer stem cells and increases their response to chemotherapy in mice. Gastroenterology 140 (1), 297309.

Lu, J., Ye, X., Fan, F., Xia, L., Bhattacharya, R., Bellister, S., Tozzi, F., Sceusi, E., Zhou, Y., Tachibana, I., Maru, D.M., Hawke, D.H., Rak, J., Mani, S.A., ZweidlerMcKay, P., Ellis, L.M., 2013. Endothelial cells promote the colorectal cancer stem cell phenotype through a soluble form of Jagged-1. Cancer Cell 23 (2), $171-185$.

Luzzi, K.J., MacDonald, I.C., Schmidt, E.E., Kerkvliet, N., Morris, V.L., Chambers, A.F., Groom, A.C., 1998. Multistep nature of metastatic inefficiency: dormancy of solitary cells after successful extravasation and limited survival of early micrometastases. Am. J. Pathol. 153 (3), $865-873$.

Lynch, C.C., Hikosaka, A., Acuff, H.B., Martin, M.D., Kawai, N., Singh, R.K., Vargo-Gogola, T.C., Begtrup, J.L., Peterson, T.E., Fingleton, B., Shirai, T., Matrisian, L.M., Futakuchi, M., 2005. MMP-7 promotes prostate cancer-induced osteolysis via the solubilization of RANKL. Cancer Cell 7 (5), $485-496$.

Madison, B.B., Braunstein, K., Kuizon, E., Portman, K., Qiao, X.T., Gumucio, D.L., 2005. Epithelial hedgehog signals pattern the intestinal crypt-villus axis. Development 132, 279-289.

Magee, J.A., Piskounova, E., Morrison, S.J., 2012. Cancer stem cells: impact, heterogeneity, and uncertainty. Cancer Cell 21 (3), $283-296$.

Marshall, J., 2006. Clinical implications of the mechanism of epidermal growth factor receptor inhibitors. Cancer 107 (6), $1207-1218$.

Marusyk, A., Almendro, V., Polyak, K., 2012. Intra-tumour heterogeneity: a looking glass for cancer? Nat. Rev. Cancer 12 (5), $323-334$.

Merlos-Suárez, A., Barriga, F.M., Jung, P., Iglesias, M., Céspedes, M.V., Rossell, D., Sevillano, M., Hernando-Momblona, X., da Silva-Diz, V., Muñoz, P., Clevers, H., Sancho, E., Mangues, R., Batlle, E., 2011. The intestinal stem cell signature identifies colorectal cancer stem cells and predicts disease relapse. Cell Stem Cell 8 (5), 511-524.

Miyazono, K., Kamiya, Y., Morikawa, M., 2010. Bone morphogenetic protein receptors and signal transduction. J. Biochem. 147 (1), $35-51$.

Moitra, K., Lou, H., Dean, M., 2011. Multidrug efflux pumps and cancer stem cells: insights into multidrug resistance and therapeutic development. Clin. Pharmacol. Ther. 89 (4), 491-502.

Morrison, S.J., Spradling, A.C., 2008. Stem cells and niches: mechanisms that promote stem cell maintenance throughout life. Cell 132 (4), 598-611.

Moustakas, A., Heldin, C.H., 2007. Signaling networks guiding epithelial-mesenchymal transitions during embryogenesis and cancer progression. Cancer Sci. 98 (10), 1512-1520.

Múzes, G., Molnár, B., Sipos, F., 2012. Regulatory T cells in inflammatory bowel diseases and colorectal cancer. World J. Gastroenterol. 18 (40), 5688-5694.

Nakamura, M., Okano, H., Blendy, J.A., Montell, C., 1994. Musashi, a neural RNA-binding protein required for Drosophila adult external sensory organ development. Neuron 13 (1), 67-81.

Naor, D., Sionov, R.V., Ish-Shalom, D., 1997. CD44: structure, function, and association with the malignant process. Adv. Cancer Res. 71, 241-319.

Nishimura, S., Wakabayashi, N., Toyoda, K., Kashima, K., Mitsufuji, S., 2003. Expression of Musashi-1 in human normal colon crypt cells: a possible stem cell marker of human colon epithelium. Dig. Dis. Sci. 48 (8), 1523-1529.

O'Brien, C.A., Pollett, A., Gallinger, S., Dick, J.E., 2007. A human colon cancer cell capable of initiating tumour growth in immunodeficient mice. Nature 445 (7123), 106-110.

Pàez-Ribes, M., Allen, E., Hudock, J., Takeda, T., Okuyama, H., Viñals, F., Inoue, M., Bergers, G., Hanahan, D., Casanovas, O., 2009. Antiangiogenic therapy elicits malignant progression of tumors to increased local invasion and distantmetastasis. Cancer Cell 15 (3), $220-231$.

Pagès, F., Galon, J., Dieu-Nosjean, M.C., Tartour, E., Sautès-Fridman, C., Fridman, W.H., 2010. Immune infiltration in human tumors: a prognostic factor that should not be ignored. Oncogene 29 (8), 1093-1102.

Palucka, A.K., Ueno, H., Fay, J., Banchereau, J., 2008. Dendritic cells: a critical player in cancer therapy? J. Immunother. 31 (9), $793-805$.

Parsons, D.W., Wang, T.L., Samuels, Y., Bardelli, A., Cummins, J.M., DeLong, L., Silliman, N., Ptak, J., Szabo, S., Willson, J.K., Markowitz, S., Kinzler, K.W., Vogelstein, B., Lengauer, C., Velculescu, V.E., 2005. Colorectal cancer: mutations in a signalling pathway. Nature 436 (7052), 792.

Paulus, U., Potten, C.S., Loeffler, M., 1992. A model of the control of cellular regeneration in the intestinal crypt after perturbation based solely on local stem cell regulation. Cell Prolif. 25 (6), 559-578.

Peeters, M., Price, T.J., Cervantes, A., Sobrero, A.F., Ducreux, M., Hotko, Y., André, T., Chan, E., Lordick, F., Punt, C.J., Strickland, A.H., Wilson, G., Ciuleanu, T.E., Roman, L., Van Cutsem, E., Tzekova, V., Collins, S., Oliner, K.S., Rong, A., Gansert, J., 2010. Randomized phase III study of panitumumab with fluorouracil, leucovorin, and irinotecan (FOLFIRI) compared with FOLFIRI alone as second-line treatment in patients with metastatic colorectal cancer. J. Clin. Oncol. 28 (31), 4706-4713.

Peng, J., Lu, J.J., Zhu, J., Xu, Y., Lu, H., Lian, P., Cai, G., Cai, S., 2008. Prediction of treatment outcome by CD44v6 after total mesorectal excision in locally advanced rectal cancer. Cancer J. 14 (1), 54-61.

Persad, S., Troussard, A.A., McPhee, T.R., Mulholland, D.J., Dedhar, S., 2001. Tumor suppressor PTEN inhibits nuclear accumulation of beta-catenin and T cell/ lymphoid enhancerfactor 1-mediated transcriptional activation. J. Cell Biol, 153 (6), 1161-1174.

Ponta, H., Sherman, L., Herrlich, P.A., 2003. CD44: from adhesion molecules to signalling regulators. Nat. Rev. Mol. Cell Biol. 4 (1), $33-45$.

Potten, C.S., Booth, C., Tudor, G.L., Booth, D., Brady, G., Hurley, P., Ashton, G., Clarke, R., Sakakibara, S., Okano, H., 2003. Identification of a putative intestinal stem cell and early lineage marker; musashi-1. Differentiation 71 (1), 28-41. 
Powell, D.W., Mifflin, R.C., Valentich, J.D., Crowe, S.E., Saada, J.I., West, A.B., 1999. Myofibroblasts. II intestinal subepithelial myofibroblasts. Am. J. Physiol. 277, C183-C201.

Prat, A., Casado, E., Cortés, J., 2007. New approaches in angiogenic targeting for colorectal cancer. World J. Gastroenterol. 13 (44), $5857-5866$.

Prince, M.E., Sivanandan, R., Kaczorowski, A., Wolf, G.T., Kaplan, M.J., Dalerba, P., Weissman, I.L., Clarke, M.F., Ailles, L.E., 2007. Identification of a subpopulation of cells with cancer stem cell properties in head andneck squamous cell carcinoma. Proc. Natl. Acad. Sci. USA 104 (3), $973-978$.

Rahme, E., Barkun, A.N., Toubouti, Y., Bardou, M., 2003. The cyclooxygenase-2-selective inhibitors rofecoxib and celecoxib prevent colorectal neoplasia occurrence andrecurrence. Gastroenterology 125 (2), 404-412.

Ramakrishnan, R., Assudani, D., Nagaraj, S., Hunter, T., Cho, H.I., Antonia, S., Altiok, S., Celis, E., Gabrilovich, D.I., 2010. Chemotherapy enhances tumor cell susceptibility to CTL-mediated killing during cancer immunotherapy in mice. J. Clin. Invest. 120 (4), 1111-1124.

Raulet, D.H., 2004. Interplay of natural killer cells and their receptors with the adaptive immune response. Nat. Immunol. 5 (10), $996-1002$.

Reeder, J.A., Gotley, D.C., Walsh, M.D., Fawcett, J., Antalis, T.M., 1998. Expression of antisense CD44 variant 6 inhibits colorectal tumor metastasis and tumor growth in a wound environment. Cancer Res. 58 (16), 3719-3726.

Ribatti, D., Ennas, M.G., Vacca, A., Ferreli, F., Nico, B., Orru, S., Sirigu, P., 2003. Tumor vascularity and tryptase-positive mast cells correlate with a poor prognosis in melanoma. Eur. J. Clin. Invest. 33 (5), 420-425.

Ricci-Vitiani, L., Lombardi, D.G., Pilozzi, E., Biffoni, M., Todaro, M., Peschle, C., De Maria, R., 2007. Identification and expansion of human colon-cancerinitiating cells. Nature 445 (7123), 111-115.

Rider, C.C., Mulloy, B., 2010. Bone morphogenetic protein and growth differentiation factor cytokine families and their protein antagonists. Biochem. J. 429 (1), 1-12.

Robert, C., Thomas, L., Bondarenko, I., O’Day, S., M D, J.W., Garbe, C., Lebbe, C., Baurain, J.F., Testori, A., Grob, J.J., Davidson, N., Richards, J., Maio, M., Hauschild, A., Miller Jr., W.H., Gascon, P., Lotem, M., Harmankaya, K., Ibrahim, R., Francis, S., Chen, T.T., Humphrey, R., Hoos, A., Wolchok, J.D., 2011. Ipilimumab plus dacarbazine for previously untreated metastatic melanoma. N. Engl. J. Med. 364 (26), 2517-2526.

Rubio, D., Garcia, S., De la Cueva, T., Paz, M.F., Lloyd, A.C., Bernad, A., Garcia-Castro, J., 2008. Human mesenchymal stem cell transformation is associated with a mesenchymal-epithelial transition. Exp. Cell Res. 314 (4), 691-698.

Sadanandam, A., Lyssiotis, C.A., Homicsko, K., Collisson, E.A., Gibb, W.J., Wullschleger, S., Ostos, L.C., Lannon, W.A., Grotzinger, C., Del Rio, M., Lhermitte, B., Olshen, A.B., Wiedenmann, B., Cantley, L.C., Gray, J.W., Hanahan, D., 2013. A colorectal cancer classification system that associates cellular phenotype and responses to therapy. Nat. Med. 19 (5), 619-625.

Salmon, S.E., Hamburger, A.W., Soehnlen, B., Durie, B.G., Alberts, D.S., Moon, T.E., 1978. Quantitation of differential sensitivity of human-tumor stem cells to anticancer drugs. N. Engl. J. Med. 298 (24), 1321-1327.

Samson, D.J., Seidenfeld, J., Ziegler, K., Aronson, N., 2004. Chemotherapy sensitivity and resistance assays: a systematic review. J. Clin. Oncol. 22 (17), $3618-$ 3630.

Sangiorgi, E., Capecchi, M.R., 2008. Bmi1 is expressed in vivo in intestinal stem cells. Nat. Genet. 40 (7), 915-920.

Sato, T., Vries, R.G., Snippert, H.J., van de Wetering, M., Barker, N., Stange, D.E., van Es, J.H., Abo, A., Kujala, P., Peters, P.J., Clevers, H., 2009. Single Lgr5 stem cells build crypt-villus structures in vitro without a mesenchymal niche. Nature 459 (7244), 262-265.

Schatton, T., Murphy, G.F., Frank, N.Y., Yamaura, K., Waaga-Gasser, A.M., Gasser, M., Zhan, Q., Jordan, S., Duncan, L.M., Weishaupt, C., Fuhlbrigge, R.C., Kupper, T.S., Sayegh, M.H., Frank, M.H., 2008. Identification of cells initiating human melanomas. Nature 451 (7176), 345-349.

Schorey, J.S., Bhatnagar, S., 2008. Exosome function: from tumor immunology to pathogen biology. Traffic. 9 (6), 871-881.

Schrag, D., Garewal, H.S., Burstein, H.J., Samson, D.J., Von Hoff, D.D., Somerfield, M.R., ASCO Working Group on Chemotherapy Sensitivity and Resistance Assays, 2004. American society of clinical oncology technology assessment: chemotherapy sensitivity and resistance assays. J. Clin. Oncol. 22 (17), $3631-3638$.

Screaton, G.R., Bell, M.V., Jackson, D.G., Cornelis, F.B., Gerth, U., Bell, J.I., 1992. Genomic structure of DNA encoding the lymphocyte homing receptor CD44 reveals at least 12 alternatively spliced exons. Proc. Natl. Acad. Sci. USA 89 (24), 12160-12164.

Shah, S.P., Morin, R.D., Khattra, J., Prentice, L., Pugh, T., Burleigh, A., Delaney, A., Gelmon, K., Guliany, R., Senz, J., Steidl, C., Holt, R.A., Jones, S., Sun, M., Leung, G., Moore, R., Severson, T., Taylor, G.A., Teschendorff, A.E., Tse, K., Turashvili, G., Varhol, R., Warren, R.L., Watson, P., Zhao, Y., Caldas, C., Huntsman, D., Hirst, M., Marra, M.A., Aparicio, S., 2009. Mutational evolution in a lobular breast tumour profiled at single nucleotide resolution. Nature 461 (7265), 809-813.

Shiao, S.L., Ganesan, A.P., Rugo, H.S., Coussens, L.M., 2011. Immune microenvironments in solid tumors: new targets for therapy. Genes Dev. 25 (24), $2559-$ 2572.

Shmelkov, S.V., Butler, J.M., Hooper, A.T., Hormigo, A., Kushner, J., Milde, T., St Clair, R., Baljevic, M., White, I., Jin, D.K., Chadburn, A., Murphy, A.J., Valenzuela, D.M., Gale, N.W., Thurston, G., Yancopoulos, G.D., D’Angelica, M., Kemeny, N., Lyden, D., Rafii, S., 2008. CD133 expression is not restricted to stem cells, and both CD133+ and CD133- metastatic colon cancer cells initiate tumors. J. Clin. Invest. 118 (6), 2111-2120.

Shtutman, M., Zhurinsky, J., Simcha, I., Albanese, C., D’Amico, M., Pestell, R., Ben-Ze'ev, A., 1999. The cyclin D1 gene is a target of the beta-catenin/LEF-1 pathway. Proc. Natl. Acad. Sci. USA 96 (10), 5522-5527.

Sidler, D., Renzulli, P., Schnoz, C., Berger, B., Schneider-Jakob, S., Flück, C., Inderbitzin, D., Corazza, N., Candinas, D., Brunner, T., 2011. Colon cancer cells produce immunoregulatory glucocorticoids. Oncogene 30 (21), 2411-2419.

Singh, S.K., Hawkins, C., Clarke, I.D., Squire, J.A., Bayani, J., Hide, T., Henkelman, R.M., Cusimano, M.D., Dirks, P.B., 2004. Identification of human brain tumour initiating cells. Nature 432 (7015), 396-401.

Stoecklein, N.H., Klein, C.A., 2010. Genetic disparity between primary tumours, disseminated tumour cells, and manifest metastasis. Int. J. Cancer 126 (3), 589-598.

Stratton, M.R., 2011. Exploring the genomes of cancer cells: progress and promise. Science 331 (6024), 1553-1558.

Sun, Y., Nelson, P.S., 2012. Molecular pathways: involving microenvironment damage responses in cancer therapy resistance. Clin. Cancer Res. 18 (15), 4019-4025.

Sureban, S.M., May, R., George, R.J., Dieckgraefe, B.K., McLeod, H.L., Ramalingam, S., Bishnupuri, K.S., Natarajan, G., Anant, S., Houchen, C.W., 2008. Knockdown of RNA binding protein musashi-1 leads to tumor regression in vivo. Gastroenterology 134 (5), 1448-1458.

Suzuki, A., Sekiya, S., Gunshima, E., Fujii, S., Taniguchi, H., 2010. EGF signaling activates proliferation and blocks apoptosis of mouse and human intestinal stem/progenitor cells inlong-term monolayer cell culture. Lab. Invest. 90 (10), 1425-1436.

Takahashi, Y., Ellis, L.M., Mai, M., 2003. The angiogenic switch of human colon cancer occurs simultaneous to initiation of invasion. Oncol. Rep. 10 (1), 9-13.

Tallerico, R., Todaro, M., Di Franco, S., Maccalli, C., Garofalo, C., Sottile, R., Palmieri, C., Tirinato, L., Pangigadde, P.N., La Rocca, R., Mandelboim, O., Stassi, G., Di Fabrizio, E., Parmiani, G., Moretta, A., Dieli, F., Kärre, K., Carbone, E., 2013. Human NK cells selective targeting of colon cancer-initiating cells: a role for natural cytotoxicity receptors and MHC class I molecules. J. Immunol. 190 (5), 2381-2390.

Taylor, D.D., Gercel-Taylor, C., 2008. MicroRNA signatures of tumor-derived exosomes as diagnostic biomarkers of ovarian cancer. Gynecol. Oncol. 110 (1), $13-21$.

Testori, A., Richards, J., Whitman, E., Mann, G.B., Lutzky, J., Camacho, L., Parmiani, G., Tosti, G., Kirkwood, J.M., Hoos, A., Yuh, L., Gupta, R., Srivastava, P.K., C100-21 Study Group, 2008. Phase III comparison of vitespen, an autologous tumor-derived heat shock protein gp96 peptide complex vaccine, with physician's choice of treatment for stage IV melanoma: the C-100-21 study group. J. Clin. Oncol. 26 (6), 955-962.

Tetsu, O., McCormick, F., 1999. Beta-catenin regulates expression of cyclin D1 in colon carcinoma cells. Nature 398 (6726), 422-426.

Thiery, J.P., Acloque, H., Huang, R.Y., Nieto, M.A., 2009. Epithelial-mesenchymal transitions in development and disease. Cell 139 (5), $871-890$.

Todaro, M., Alea, M.P., Di Stefano, A.B., Cammareri, P., Vermeulen, L., Iovino, F., Tripodo, C., Russo, A., Gulotta, G., Medema, J.P., Stassi, G., 2007. Colon cancer stem cells dictate tumor growth and resist cell death by production of interleukin-4. Cell Stem Cell 1 (4), 389-402.

Todaro, M., Perez Alea, M., Scopelliti, A., Medema, J.P., Stassi, G., 2008. IL-4-mediated drug resistance in colon cancer stem cells. Cell Cycle 7 (3), $309-313$. 
Todaro, M., D’Asaro, M., Caccamo, N., Iovino, F., Francipane, M.G., Meraviglia, S., Orlando, V., La Mendola, C., Gulotta, G., Salerno, A., Dieli, F., Stassi, G., 2009. Efficient killing of human colon cancer stem cells by gammadelta T lymphocytes. J. Immunol. 182 (11), 7287-7296.

Tokarz, P., Blasiak, J., 2012. The role of microRNA in metastatic colorectal cancer and its significance in cancer prognosis and treatment. Acta Biochim. Pol. 59 (4), 467-474.

Tremmel, M., Matzke, A., Albrecht, I., Laib, A.M., Olaku, V., Ballmer-Hofer, K., Christofori, G., Héroult, M., Augustin, H.G., Ponta, H., Orian-Rousseau, V., 2009. A CD44v6 peptide reveals a role of CD44 in VEGFR-2 signaling and angiogenesis. Blood 114 (25), 5236-5244.

Valastyan, S., Weinberg, R.A., 2011. Tumor metastasis: molecular insights and evolving paradigms. Cell 147 (2), 275-292.

Valent, P., Bonnet, D., De Maria, R., Lapidot, T., Copland, M., Melo, J.V., Chomienne, C., Ishikawa, F., Schuringa, J.J., Stassi, G., Huntly, B., Herrmann, H., Soulier, J., Roesch, A., Schuurhuis, G.J., Wöhrer, S., Arock, M., Zuber, J., Cerny-Reiterer, S., Johnsen, H.E., Andreeff, M., Eaves, C., 2012. Cancer stem cell definitions and terminology: the devil is in the details. Nat. Rev. Cancer 12 (11), 767-775.

Van Cutsem, E., Peeters, M., Siena, S., Humblet, Y., Hendlisz, A., Neyns, B., Canon, J.L., Van Laethem, J.L., Maurel, J., Richardson, G., Wolf, M., Amado, R.G., 2007. Open-label phase III trial of panitumumab plus best supportive care compared with best supportive care alone inpatients with chemotherapy-refractory metastatic colorectal cancer. J. Clin. Oncol. 25 (13), 1658-1664.

Van Cutsem, E., Köhne, C.H., Hitre, E., Zaluski, J., Chang Chien, C.R., Makhson, A., D’Haens, G., Pintér, T., Lim, R., Bodoky, G., Roh, J.K., Folprecht, G., Ruff, P., Stroh, C., Tejpar, S., Schlichting, M., Nippgen, J., Rougier, P., 2009. Cetuximab and chemotherapy as initial treatment for metastatic colorectal cancer. N. Engl. J. Med. 360 (14), 1408-1417.

van Es, J.H., Clevers, H., 2005. Notch and Wnt inhibitors as potential new drugs for intestinal neoplastic disease. Trends Mol. Med. 11, 496-502.

van Es, J.H., Jay, P., Gregorieff, A., van Gijn, M.E., Jonkheer, S., Hatzis, P., Thiele, A., van den Born, M., Begthel, H., Brabletz, T., Taketo, M.M., Clevers, H., 2005. Wnt signalling induces maturation of paneth cells in intestinal crypts. Nat. Cell Biol. 7 (4), 381-386.

van Es, J.H., de Geest, N., van de Born, M., Clevers, H., Hassan, B.A., 2010. Intestinal stem cells lacking the math1 tumour suppressor are refractory to notch inhibitors. Nat. Commun. 17 (1), 18.

Vermeulen, L., Todaro, M., de Sousa Mello, F., Sprick, M.R., Kemper, K., Perez Alea, M., Richel, D.J., Stassi, G., Medema, J.P., 2008. Single-cell cloning of colon cancer stem cells reveals a multi-lineage differentiation capacity. Proc. Natl. Acad. Sci. USA 105 (36), 13427-13432.

Vermeulen, L., De Sousa, E., Melo, F., van der Heijden, M., Cameron, K., de Jong. J.H., Borovski, T., Tuynman, J.B., Todaro, M., Merz, C., Rodermond, H., Sprick, M.R., Kemper, K., Richel, D.J., Stassi, G., Medema, J.P., 2010. Wnt activity defines colon cancer stem cells and is regulated by the microenvironment. Nat. Cell Biol. 12, 468-476

Vesely, M.D., Kershaw, M.H., Schreiber, R.D., Smyth, M.J., 2011. Natural innate and adaptive immunity to cancer. Annu. Rev. Immunol. 29, 235-271.

Viey, E., Lucas, C., Romagne, F., Escudier, B., Chouaib, S., Caignard, A., 2008. Chemokine receptors expression and migration potential of tumor-infiltrating and peripheral-expanded Vgamma9Vdelta2 T cells from renal cell carcinoma patients. J. Immunother. 31 (3), 313-323.

Vogelstein, B., Fearon, E.R., Hamilton, S.R., Kern, S.E., Preisinger, A.C., Leppert, M., Nakamura, Y., White, R., Smits, A.M., Bos, J.L., 1988. Genetic alterations during colorectal-tumor development. N. Engl. J. Med. 19 (9), 525-532.

Von Hoff, D.D., Clark, G.M., Stogdill, B.J., Sarosdy, M.F., O’Brien, M.T., Casper, J.T., Mattox, D.E., Page, C.P., Cruz, A.B., Sandbach, J.F., 1983. Prospective clinical trial of a human tumor cloning system. Cancer Res. 43 (4), 1926-1931.

Von Hoff, D.D., Kronmal, R., Salmon, S.E., Turner, J., Green, J.B., Bonorris, J.S., Moorhead, E.L., Hynes, H.E., Pugh, R.E., Belt, R.J., et al, 1991. A Southwest oncology group study on the use of a human tumor cloning assay for predicting response in patients with ovarian cancer. Cancer 67 (1), $20-27$.

Waite, K.A., Eng, C., 2003. BMP2 exposure results in decreased PTEN protein degradation and increased PTEN levels. Hum. Mol. Genet. 12, 679-684.

Warburg, O., Wind, F., Negelein, E., 1927. The metabolism of tumors in the body. J. Gen. Physiol. 8 (6), $519-530$.

Wielenga, V.J., Heider, K.H., Offerhaus, G.J., Adolf, G.R., van den Berg, F.M., Ponta, H., Herrlich, P., Pals, S.T., 1993. Expression of CD44 variant proteins in human colorectal cancer is related to tumor progression. Cancer Res. 53 (20), 4754-4756.

Wilson, P.M., Ladner, R.D., Lenz, H.J., 2007. Exploring alternative individualized treatment strategies in colorectal cancer. Clin. Colorectal Cancer 1 (Suppl.), S28-S36.

Wolmark, N., Rockette, H., Fisher, B., Wickerham, D.L., Redmond, C., Fisher, E.R., Jones, J., Mamounas, E.P., Ore, L., Petrelli, N.J., et al, 1993. The benefit of leucovorin-modulated fluorouracil as postoperative adjuvant therapy for primary colon cancer: results from national surgical adjuvant breast and bowel project protocol C-03. J. Clin. Oncol. 11 (10), 1879-1887.

Yachida, S., Jones, S., Bozic, I., Antal, T., Leary, R., Fu, B., Kamiyama, M., Hruban, R.H., Eshleman, J.R., Nowak, M.A., Velculescu, V.E., Kinzler, K.W., Vogelstein, B., Iacobuzio-Donahue, C.A., 2010. Distant metastasis occurs late during the genetic evolution of pancreatic cancer. Nature 467 (7319), $1114-1117$.

Yan, K.S., Chia, L.A., Li, X., Ootani, A., Su, J., Lee, J.Y., Su, N., Luo, Y., Heilshorn, S.C., Amieva, M.R., Sangiorgi, E., Capecchi, M.R., Kuo, C.J., 2012. The intestinal stem cell markers Bmi1 and Lgr5 identify two functionally distinct populations. Proc. Natl. Acad. Sci. USA 109 (2), $466-471$.

Yang, Z.F., Ho, D.W., Ng, M.N., Lau, C.K., Yu, W.C., Ngai, P., Chu, P.W., Lam, C.T., Poon, R.T., Fan, S.T., 2008. Significance of CD90+ cancer stem cells in human liver cancer. Cancer Cell 13 (2), 153-166.

Yin, A.H., Miraglia, S., Zanjani, E.D., Almeida-Porada, G., Ogawa, M., Leary, A.G., Olweus, J., Kearney, J., Buck, D.W., 1997. AC133, a novel marker for human hematopoietic stem and progenitor cells. Blood 90 (12), 5002-5012.

Yu, W.H., Woessner Jr., J.F., McNeish, J.D., Stamenkovic, I., 2002. CD44 anchors the assembly of matrilysin/MMP-7 with heparin-binding epidermal growth factor precursor and ErbB4 and regulates female reproductive organ remodeling. Genes Dev. 16 (3), $307-323$.

Zha, S., Yegnasubramanian, V., Nelson, W.G., Isaacs, W.B., De Marzo, A.M., 2004. Cyclooxygenases in cancer: progress and perspective. Cancer Lett. 215 (1), $1-20$.

Zlobec, I., Günthert, U., Tornillo, L., Iezzi, G., Baumhoer, D., Terracciano, L., Lugli, A., 2009. Systematic assessment of the prognostic impact of membranous CD44v6 protein expression in colorectal cancer. Histopathology 55 (5), 564-575.

Zou, W., 2005. Immunosuppressive networks in the tumour environment and their therapeutic relevance. Nat. Rev. Cancer 5 (4), $263-274$. 